\title{
Workforce competencies and work -based learning in Maryland community college nursing programs
}

\author{
Richard F. Ammon \\ West Virginia University
}

Follow this and additional works at: https://researchrepository.wvu.edu/etd

\section{Recommended Citation}

Ammon, Richard F., "Workforce competencies and work -based learning in Maryland community college nursing programs" (2006). Graduate Theses, Dissertations, and Problem Reports. 2695.

https://researchrepository.wvu.edu/etd/2695

This Dissertation is protected by copyright and/or related rights. It has been brought to you by the The Research Repository @ WVU with permission from the rights-holder(s). You are free to use this Dissertation in any way that is permitted by the copyright and related rights legislation that applies to your use. For other uses you must obtain permission from the rights-holder(s) directly, unless additional rights are indicated by a Creative Commons license in the record and/ or on the work itself. This Dissertation has been accepted for inclusion in WVU Graduate Theses, Dissertations, and Problem Reports collection by an authorized administrator of The Research Repository @ WVU.

For more information, please contact researchrepository@mail.wvu.edu. 
Workforce Competencies and Work-based Learning in Maryland Community College Nursing Programs

\author{
Richard F. Ammon
}

\author{
Dissertation submitted to the \\ College of Human Resources and Education \\ at West Virginia University \\ in partial fulfillment of the requirements \\ for the degree of
}

\author{
Doctor of Education \\ in \\ Educational Leadership Studies \\ Richard Hartnett, Ed.D., Chair \\ Paul Chapman, Ph.D \\ Ernest Goeres, Ph.D. \\ David McCrory, Ph.D. \\ Richard Yankosky, Ed.D. \\ Department of Advanced Educational Studies
}

Morgantown, West Virginia

2006

Keywords: Workforce Competencies, Work-based Learning, Nursing Programs

Copyright 2006 Richard Ammon 


\begin{abstract}
Workplace Competency Development of Maryland Community College Nursing Students: Do Community College Nursing Students Who Participated In A Work-Based Learning Clinical Experience Develop Basic Workplace Competencies Necessary To Work Effectively In The Workplace.
\end{abstract}

\title{
Richard Ammon
}

This study assessed whether Maryland community college students who participated in the first semester of a nursing work-based learning clinical experience during the fall 2004 semester perceived that they developed basic workplace competencies necessary to work effectively in the workplace. The total population of the study consisted of 264 nursing students from eight Maryland Community Colleges. The research questions guiding this study were answered using descriptive statistics, t-tests, and an analysis of variance (ANOVA).

Major findings indicated that contrary to the hypothesis of the study, instead of showing a gain in competency scores, eight of nine workplace competencies decreased and three of the eight were significantly different. There was no significant differences between the pre-clinical and post-clinical scores of students' from schools that reflected exemplary policies and procedures and schools that did not reflect exemplary policies and procedures. Within exemplary and non-exemplary schools analysis revealed that students from schools that did not reflect exemplary policies and procedures did show significant differences in their mean scores. Research showed that there were no significant differences in the students' competency scores based on each student's years of previous work experience. Significant differences were seen in the competency scores of students grouped by age. A significant difference was also seen between students with different levels of academic achievement. There were also significant differences seen between students based on the number of credits being awarded for the completion of the clinical experience. No significant differences were found between the mean scores based on the size of the student's institution. There was no significant difference found in the student's pre-clinical scores or post-clinical scores based on the number of nursing students enrolled in the student's nursing degree program. 


\section{DEDICATION}

This study is dedicated to my wife, Michelle M. Ammon. Her constant support and dedication allowed me to find the strength to persist. Although this study was initially my dream, she quickly accepted the sacrifices needed to make this dream a reality. For that I am eternally grateful. This study is also dedicated to my parents. Their initial support of my pursuit of higher education enabled me to start on this journey. 


\section{ACKNOWLEDGEMENTS}

The people that accomplish great things in life have one thing in common, someone who saw the potential in that person and provided an opportunity for that person to grow. I am truly lucky in the fact that I am surrounded by many people that saw potential in me and provided me the support to accomplish my goals. I know that the primary reason I am where I am today is due to your support, and without that support, I could not have made my goal a reality. I will be eternally grateful.

Committee Members

Richard Hartnett, Ed.D., Chair

Paul Chapman, Ph.D

Ernest Goeres, Ph.D.

David McCrory, Ph.D.

Richard Yankosky, Ed.D.

WVU Faculty

Elizabeth Jones, Ph.D

Friends

Jeanette Beaver

Richard Noriekes

Robin Spaid

Doug Leather

Frederick Community College

Carol Eaton

Doug Holt

Kate Scangarello

Patricia Stanley

Robert Young 
Table of Contents

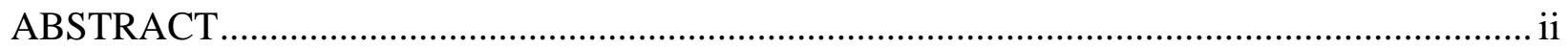

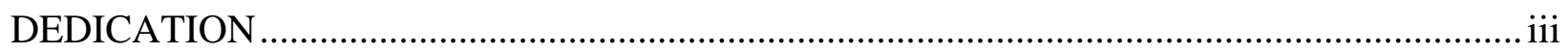

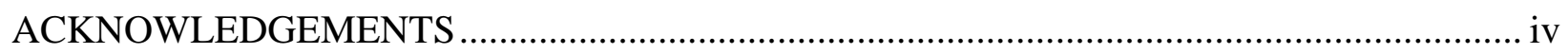

Table of Contents .........................................................................................................

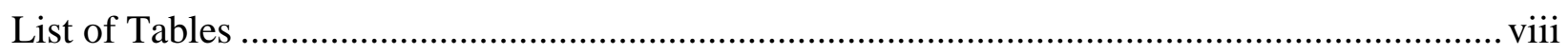

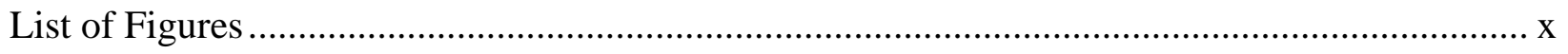

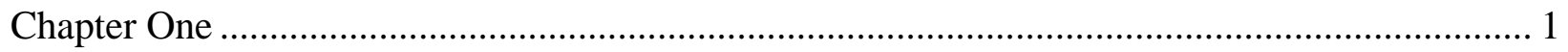

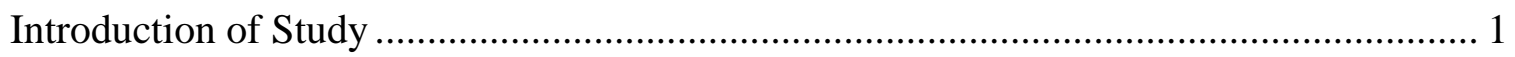

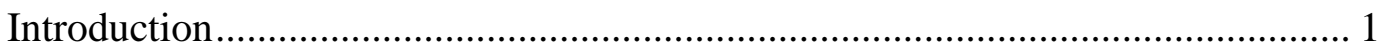

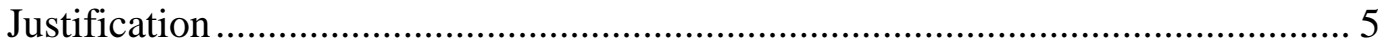

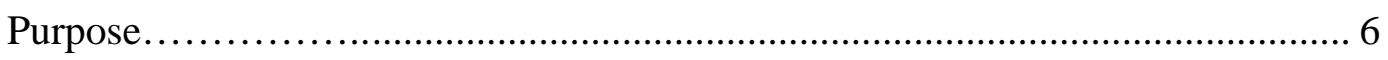

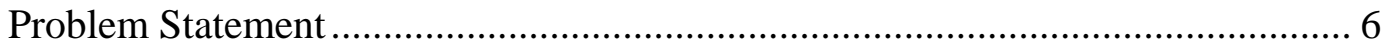

Research Questions.............................................................................. 6

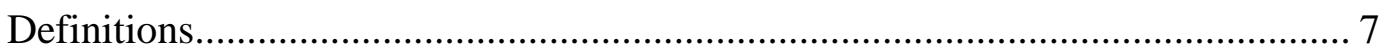

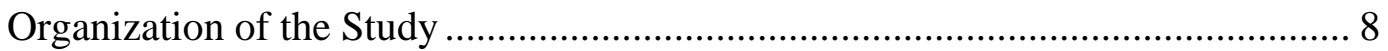

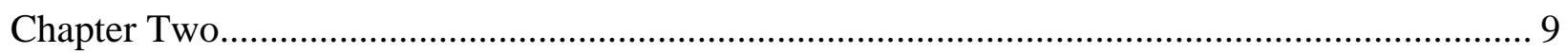

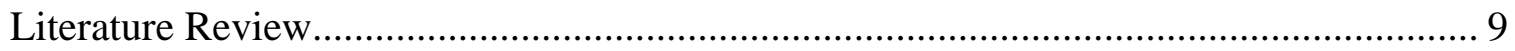

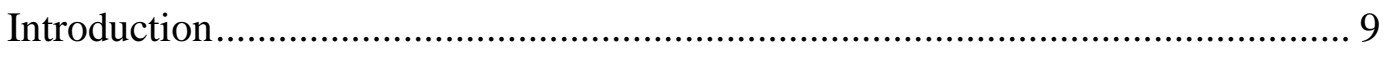

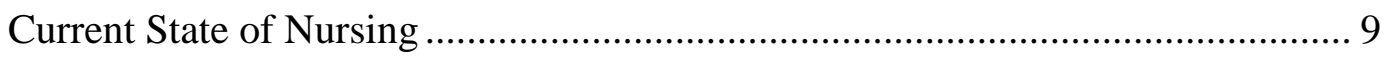

The Changing Mission of the Community College .......................................... 12

The Community College Role in Occupational Education............................... 17

Workplace Competencies Defined ........................................................... 20

Research of Workplace Competencies ...................................................... 23 
Workplace Competencies Skills Gap in Nursing Education ............................. 24

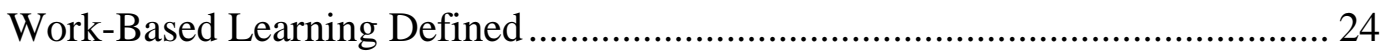

Characteristics of Exemplary Work-based Learning Programs........................... 29

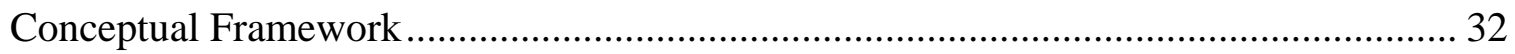

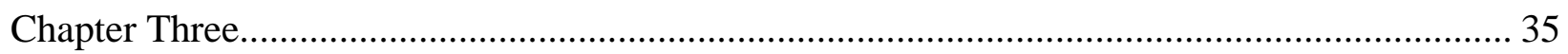

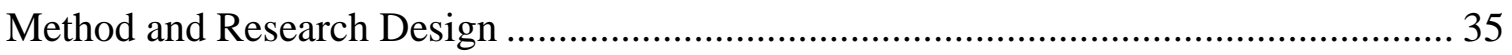

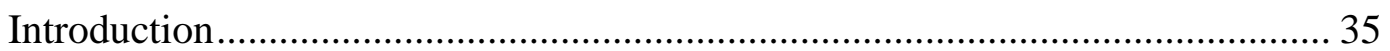

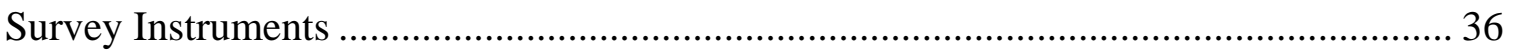

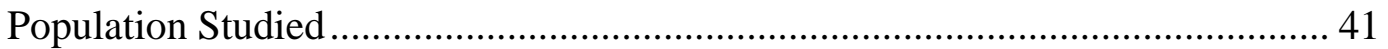

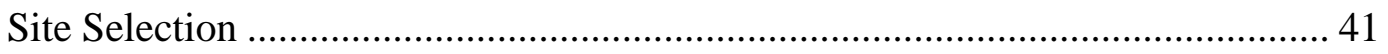

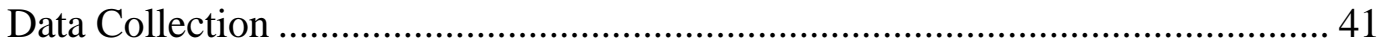

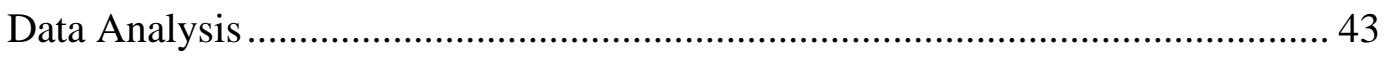

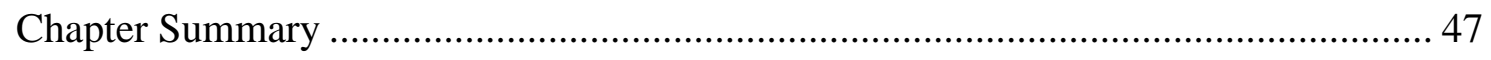

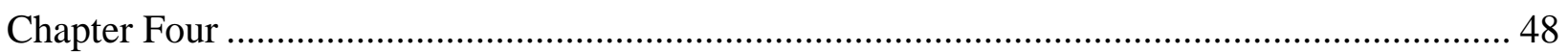

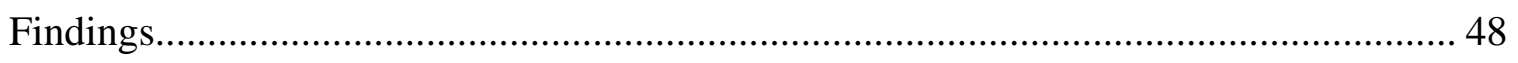

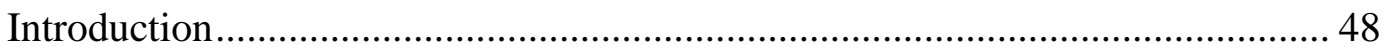

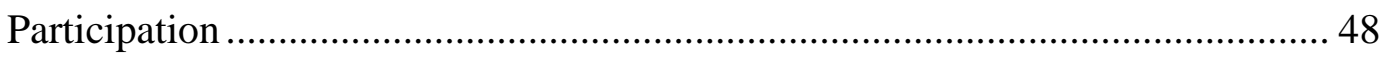

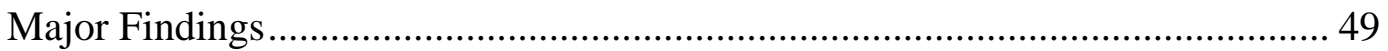

Research Question One............................................................... 49

Research Question Two .............................................................. 51

Research Question Three ............................................................. 54

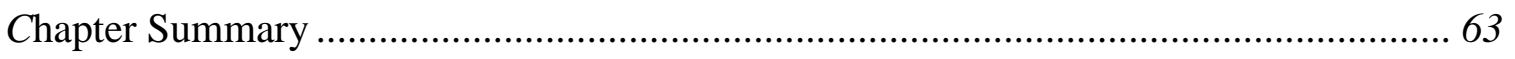

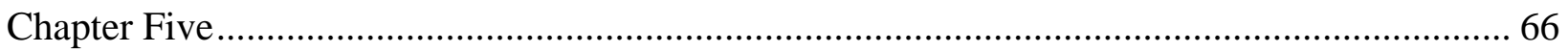

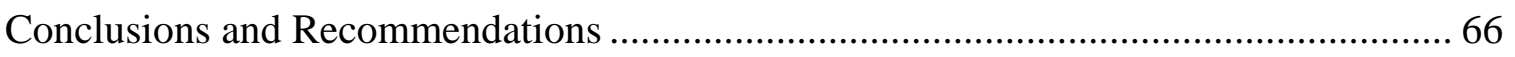




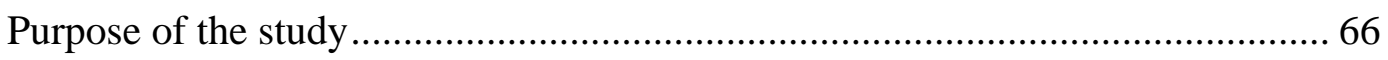

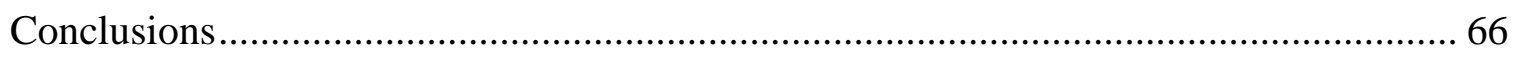

Research Question One....................................................................................... 66

Research Question Two .................................................................................... 69

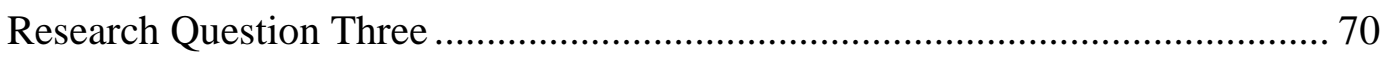

Summary Conlusion........................................................................................ 72

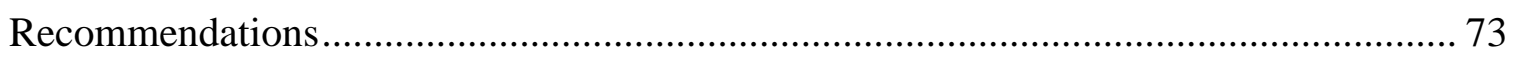

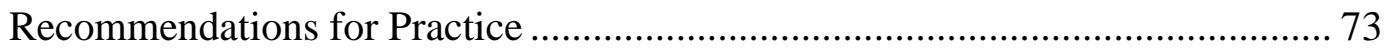

Recommendations for Further Research............................................................. 74

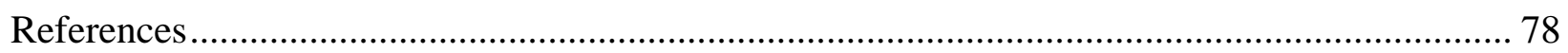

Appendix A Nursing Program Coordinator Interview Questionnaire ........................................... 88

Appendix B Pre-clinical Experience Cover Letter to the Nursing Program Coordinator ............. 89

Appendix C Work-based Learning Program Dimensions Questionnaire to the Nursing

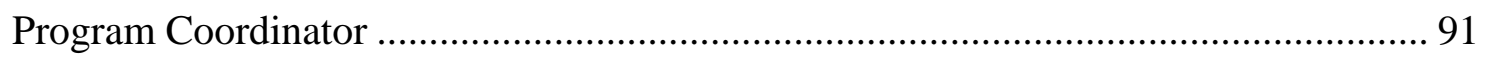

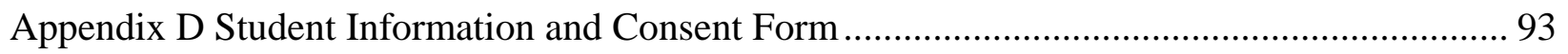

Appendix E Pre-clinical Experience Student Demographic Characteristic Questionnaire ........... 96

Appendix F Post-clinical Experience Cover Letter to Students …………………......................... 97

Appendix G Post-clinical Experience Abbreviated Student Questionnaire ……………............... 98 


\section{List of Tables}

Table 1 Instruments, Appendix, and Respondents 36

Table 2 Minimum and Maximum Workplace Competency Scores Attainable on the Working: Assessing Skills, Habits, and Style Questionnaire by Workplace

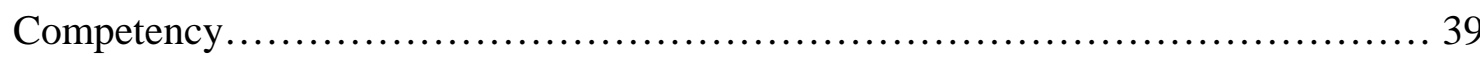

Table 3 Data that was used for Evaluating the Research Questions....................................... 44

Table 4 Analysis to be used by Research Variable.................................... 46

Table 5 Student Characteristics and Demographic Data of Respondents.................... 50

Table 6 Differences on Working: Assessing Skills, Habits, and Style Questionnaire by

Pre-clinical and Post-clinical Scores............................................. 52

Table 7 Differences on Working: Assessing Skills, Habits, and Style Questionnaire Pre-clinical and Post-clinical Scores, Between Students Enrolled in Exemplary and Non-exemplary Nursing Programs...................................... 53

Table 8 Differences on Working: Assessing Skills, Habits, and Style Questionnaire Pre-clinical and Post-clinical Scores, Within Exemplary and Non-exemplary

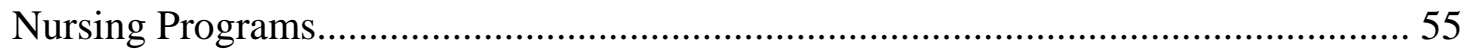

Table 9 Differences on Working: Assessing Skills, Habits, and Style Questionnaire Pre-clinical and Post-clinical Scores, Between Groups with Different Years of Previous Work Experience............................................. 56

Table 10 Differences on Working: Assessing Skills, Habits, and Style Questionnaire Pre-clinical and Post-clinical Scores, Between Groups with Different Years

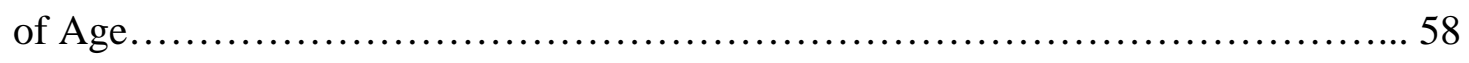


Table 11 Differences on Working: Assessing Skills, Habits, and Style Questionnaire Pre-clinical and Post-clinical Scores, Between Groups with Different Levels of Academic Achievement

Table 12 Differences on Working: Assessing Skills, Habits, and Style Questionnaire Pre-clinical and Post-clinical Scores, Between Groups with Different Number of Credits Awarded for the Completion of the Clinical Experience.................. 61 Table 13 Differences on Working: Assessing Skills, Habits, and Style Questionnaire Pre-clinical and Post-clinical Scores Between Groups by the Size of the

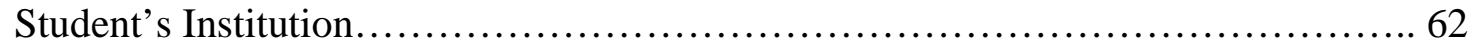

Table 14 Differences on Working: Assessing Skills, Habits, and Style Questionnaire Pre-clinical and Post-clinical Scores by the Number of Nursing Students Enrolled in the Student's Nursing Degree Program............................ 64 


\section{List of Figures}

Figure 1 Conceptual Framework................................................. 34 


\section{Chapter One \\ Introduction of Study}

\section{Introduction}

The increased complexity of the healthcare profession requires that registered nurses (RN) be better prepared in basic workplace competencies. The United States Department of Health and Human Services (USDHHS, 2001a) reports that the majority of RN's (34.3\%) are educated by community colleges. Nursing education programs at their college usually include a work-based learning clinical experience. These experiences help students gain practical experience that includes basic workplace competencies. These competencies are essential for acquiring, evaluating, and implementing new knowledge (USDHHS, 2001b). Accordingly, curricular processes and outcomes need to emphasize the attainment of these competencies.

Nurses who demonstrate these competencies are highly sought after because they quickly adapt to the changing demands of a complex work environment (Carnevale \& Desrochers, 2001; Carnevale, Gainer, \& Meltzer, 1990; Overtoom, 2000). Workplace competencies for nurses include: (a) problem solving, (b) interpersonal and communication skills, (c) critical thinking, (d) relationship management, (e) information literacy, (f) sensitivity to diversity, (g) creativity, (h) teamwork skills, and (i) ethical decision making (American Association of College Nursing [AACN], 2002; Carnevale \& Desrochers, 2001; National League of Nursing Accrediting Commission [NLNAC], 2003). The lack of basic workplace competencies is a barrier to employment (Carnevale, Gainer, \& Meltzer, 1990).

This study looked at community college students who participated in associate degree of nursing (ADN) work-based learning clinical experiences. The hypothesis of the study was that students who participated in nursing work-based learning clinical experiences developed basic workplace competencies necessary to work effectively in the workplace. 
Employees with shortages in basic workplace competencies are not new. Two reports from the late 1980's referenced the potential of a basic workplace competency skills gap between the qualifications of workers and the skills required to work efficiently in the next century. The Hudson Institute’s Workforce 2000 report (Johnston \& Packer, 1987) and the Commission on the Skills of the American Worker (CSAW) clearly stated that there would be a competency skills gap if employers in the United States decided to compete on the quality of our products and services. Workers of the future will need to possess basic workplace competencies. The ability to gain new knowledge, skills and abilities is an essential skill for employees to possess. The attainment of basic workplace competencies provides students with the building blocks to attain and master new knowledge, skills and abilities taught throughout the student's secondary and post-secondary education (Perry, 1992).

Two subsequent national reports, one by the American Society for Training and Development (ASTD; Carnevale, \& Johnston, 1989) and one by the Secretary's Commission on Achieving Necessary Skills (SCANS; U.S. Department of Labor [USDOL], 1991b) are foundational works in identifying basic workplace competencies, often used as benchmarks or beginning points for other international, national, state, regional, and local studies (Overtoom, 2000).

The National Alliance for Business conducted a study that sought to determine what the higher education community and employers expected from high school graduates. The results of the study reinforced what previous research had documented, that there is a need for a more educated workforce (National Alliance of Business [NAB], 2002b). The research found the following needs:

One key competency that employers across-the-board value in employees is the ability to think creatively and logically in order to solve problems. Such employees are most likely 
to be promoted in an unforgiving global economy that requires flexibility and an ability to develop new skills. The ability to think, speak, and write logically, to solve problems, and to synthesize information are also priority competencies cited by postsecondary faculty members from all disciplines. (The American Diploma Project, 2002, ๆ 8). Recent reform initiatives like the Tech Prep of the Occupational Education Act and the School-to-Work Opportunities Act (STWOA) legislated that community colleges take on a stronger role in the economic development of our country to address the nation's workplace competency skills shortage. The STWOA was a response by the United States Congress to the numerous reports complaining of inadequate technical skills in recent high school graduates and adult workers (Bragg \& Hamm, 1996). The goal of the act was to improve existing workforce preparation systems by bringing together employers and schools (Bragg \& Hamm, 1996) and promoted the systematic educational reform nationwide to improve the link between what is taught in the classroom and the educational needs of employees in the workplace (Laanan, 1995). Bragg and Hamm stated that work-based learning programs can be used as a strategy to help build partnerships between education and industry, enhance technical and academic skills of students, and to contribute to the nation's economic well being. Work-based learning experiences are a critical component of the school-to-work transition for students (Naylor, 1997). Laanan (1995) further explains that community colleges play an integral role in the school to career initiative because they offer work-based learning programs. Programs offered in community colleges such as tech prep, internships, apprenticeships, cooperative education, clinical experiences, and career education create the link between employers and students. It was the goal of the SWTOA to create a continuum of workplace learning where the student would attain basic workplace competencies through work-based learning in secondary schools and then build upon those skills during their post-secondary education. 
Previous studies on work-based learning programs suggest that these programs need to be assessed for their effectiveness (Stasz \& Stern, 1998). Researchers have also recommended that there is need for research that establishes the connection between the work-based learning experiences and the development of basic workplace competencies or outcomes in order to determine whether or not work-based learning is developing the intended workplace competencies and outcomes (Stasz \& Stern, 1998).

An assessment tool developed by Public Policy Associates, entitled Working: Assessing Skills, Habits, and Styles (Miles \& Grummon, 1996), was designed to determine the attainment of basic workplace competencies of students. The authors of the instrument reviewed the literature to determine the skill areas identified as critical by most employers (Maduschke \& Grummon, 1996). From the literature the authors determined that there are nine scales that were used to help measure the attainment of basic workplace competencies of students. The nine scales include: (a) taking responsibility, (b) working in teams, (c) persisting, a sense of quality, (d) life-long learning, (e) adapting to change, (f) permanent problem solving, (g) information processing, and (h) systems thinking (Maduschke \& Grummon, 1996).

Work-based learning occurs in multiple forms: contracted instruction, cooperative education, school-to-apprenticeship, registered apprenticeship, career exploration, service learning, career internships, career academies, school based enterprises, and clinical experience programs (Naylor, 1997). Naylor stated that work-based learning activities can take the form of a shorter-term introductory type of experience all the way through to a longer-term, more intensive form. Naylor describes the common elements of a work-based learning program to include: (a) a planned program of job training and experiences, (b) workplace mentoring, (c) instruction in general workplace competencies, and (d) broad instruction in all aspects of industry. 
A series of studies in the mid 1990's sought to determine the status of work-based learning in America’s two-year colleges. Bragg, Hamm, and Trinkle (1995) conducted a study to determine the quality and the extent work-based learning has been incorporated in community colleges. The purpose of this study was to gain an understanding of existing work-based learning policies, practices, and programs in two-year colleges. The second phase of the study was to identify exemplary work-based learning policies, practices, and through in-depth analysis, gain a better understanding of the selected work-based learning programs (Bragg et al., 1996). Bragg et al. (1996) stated that a very important objective of the study was "to identify common factors, elements, phenomena, activities, and issues that could help distinguish or explain exemplary policies and practices of two-year college work-based learning programs” (Bragg et al., 1996, p. 13). Bragg et al. (1996) determined that schools which were identified for having exemplary policies and practices had the following characteristics: strong program leadership; exclusive communication with local employers; beliefs about program excellence; an effective schoolbased learning component; adequate and diverse financial support, an innovative program, and pedagogical features.

\section{Justification}

Research is needed to examine the relationship between the basic workforce competencies required in the workplace and what is being taught in higher education. Overtoom (2000, p. 2) stated that the "integration of employability skills into curriculum has been a slow process.” She reported that “considerable more research is needed on creating and assessing curriculum that integrates the learning of employability skills contextually. Valid and reliable links must be forged between such curriculum and improved learner performance/competency attainment” (Overtoom, 2000, p. 2). 
Students believe their work-based learning experiences are valuable. In some cases students have reported that they discovered which direction their occupational compass was pointing as a result of work-based learning (WBL) experiences (Stasz \& Stern, 1998) as well as developing an insight into the occupations that they did not want do. Other benefits of WBL reported by Stasz and Stern included enhancement of academic achievement and motivation; an increase in personal and social competence related to work in general; gains in the broad understanding of an occupation and provisions of industry; opportunities for career exploration and planning, and acquisition of knowledge skills for particular occupations or more generic work competencies.

Purpose

The purpose of this study was to determine if community college nursing students who participated in a work-based learning clinical experience developed basic workplace competencies necessary to work effectively in the workplace.

\section{Problem Statement}

Do community college nursing students who participated in a work-based learning clinical experience demonstrate gains in their workforce competencies as measured by the Working: Assessing Skills, Habits, and Styles instrument?

\section{Research Questions}

1. What types of gains do students who participated in nursing clinical experiences demonstrate over time?

2. Are there significant differences in workforce competencies between students enrolled in nursing clinical experiences at community colleges that reflect exemplary policies and procedures versus students at community colleges that do not reflect exemplary policies and procedures? 
3. Are there significant differences in workforce competencies for students by various demographic factors and institutional variables? These factors include previous work experience, age, academic achievement, and the number of credits the student will be awarded for the completion of the clinical experience. Selected institutional variables include institutional size and the size of an institutions associate degree of nursing program; that is the number of students enrolled in the institutions associate degree of nursing program.

\section{Definitions}

Associate Degree of Nursing (ADN) Program: An educational program typically lasting two years in length. Junior or community colleges generally deliver ADN programs. The program of study results in the attainment of an associate degree. Upon completion of the major nursing students are eligible to apply for licensure as a registered nurse (ICON, 2003).

Clinical experiences: "Work site learning that occurs in association with preparation for a credential in a professional health care field” (Bragg, Hamm, \& Trinkle, 1995, p. 32).

Work-based learning: "Work-based learning includes a number of different activities that can be identified along a continuum from shorter-term introductory types of experiences to longer-term, more intensive ones, including paid work experience and formal training. It is part of a three-pronged approach to school-to-work transition that also includes school-based learning and connecting activities” (Naylor, 1997, ๆ 1).

Workforce competencies: "Skills competencies are what a person must know to handle five facets of any workplace -- resources, interpersonal relationships, information, systems and technology....Underlying these competencies is the skills foundation, which goes beyond the "three R's" to include speaking and listening skills and the thinking skills -- those creative and analytical skills necessary for problem solving and decision making. Finally, the foundation 
includes personal qualities highly prized by employers -- qualities such as responsibility, selfesteem and integrity” (USDOL, 1991a, p. 6).

Organization of the Study

This study consists of five chapters. Chapter 1 includes an introduction, background, justification, purpose, problem statement, research questions, and definitions. Chapter 2 reviews relevant literature and theory as it relates to nursing, workforce competencies, and work-based learning. Chapter 3 outlines the design and methodology of this study. Chapter 4 presents the findings and results of the research. Chapter 5 presents the conclusions and recommendations. 


\section{Chapter Two}

Literature Review

\section{Introduction}

The review of the literature examines the role community colleges in the development of basic workforce competencies. The first section of the literature review presents the current state of nursing. The second details the conflicting and changing role of workforce development in the community college. The third section defines workforce competencies, including a historical perspective of the development of workforce competencies and research on workforce development. The fourth and final section defines work-based learning in the context of developing work-based competencies through clinical experiences.

\section{Current State of Nursing}

The field of healthcare is rapidly changing. Advances in technology, pharmaceuticals, and bio-medical equipment have created an ever changing work environment for nurses. This coupled with changes in the demographic composition of patients has implications on the characteristics of the nurse workforce, their education, and how they practice (USDHHS, 2001a; USDHHS, 2001b).

The professional setting for registered nurses $(\mathrm{RN})$ has expanded from the traditional hospital environment to include: (a) nursing education institutions, (b) public health organizations, (c) community health agencies, (d) nursing homes facilities, and (e) extended care facilities (USDHHS, 2000). Hospitals employ the majority (59\%) of the RN's, down from $66 \%$ in 1992 (USDHHS, 2001b). Over this same time period the number of RN's increased 61\% in public and community health organizations and 18\% in nursing homes (USDHHS, 2001b). Public and community health settings include (a) state health agencies, (b) local health agencies, 
(c) home health agencies, (d) community-based clinics, (e) student health services, and (f) occupational health services (USDHHS, 2001b).

There is a growing trend indicating that the demand for nurses will outpace the supply by 12\% in the year 2010 and 29\% by 2020 (USDHHS, 2001b). In 2000 there were over 1.89 million registered nurses (RN's) in the United States. At the same time, the demand for RN's was estimated at 2 million, a net shortage of 110,000 RN's nationwide (USDHHS, 2002). In 2000, Maryland had an estimated nurse population of 38,291 RN's. The demand for RN's was estimated at 38,836 positions resulting in a net shortage of 545 nurses statewide (USDHHS, 2002). The continuation of this change will result in an estimated net shortage of 808,416 nurses in the United States and a net shortage of 18,954 nurses in Maryland by 2020 (USDHHS, 2002).

The shortage in nursing is primarily caused by the increased average age of the nurses in the workforce and the decline in the number of nursing program graduates (Goodin, 2003; USDHHS, 2001b, 2002). The average age of the registered nurse (RN) population has increased recently. The average age for the registered nurse population was 45.2 years of age in 2000 compared to the average of 42.3 years of age in 1996 (USDHHS, 2001a). This is further exacerbated by an increase in the average age of the nursing degree graduate (USDHHS, 2002). The nursing population in Maryland mirrors the national data with the majority (70\%) of nurses being over the age of 46 (Maryland Board of Nursing [MBON], 2002). In 2000 there was net decrease of 26\% in the number of students passing the RN National Council Licensure Examination (NCLEX) as compared to the number of students passing the NCLEX in1995 (USDHHS, 2002). The majority (94\%) of RN's in the workplace in 2000 were women (USDHHS, 2001b).

To become a registered nurse (RN), a student typically completes three steps: (a) completes a nursing program recognized by the state in which the person wants to be registered, 
(b) meets requirements set by the state board of nursing, and (c) completes the National Council of State Boards of Nursing (NCSBN) National Council Licensure Examination (NCLEX) for registered nurses (NCSBN, 2004a). The associate degree of nursing (ADN) is the foundational degree of the nursing field. In the academic year 2001-2002 over 40,086 ADN's were awarded (NCES, 2003a). The majority (55.4\%) of RN's receiving their nurse education between 1995 and 2000 graduated with an ADN (USDHHS, 2000). In 2000 that figure rose to 60\% (AACC, 2002). Forty percent of all RN's received their basic education in an associate degree program (USDHHS, 2000). Of the 2000 nursing graduates entering the field, 79\% graduated from community colleges (AACC, 2002).

Entry level registered nurse (RN) education in Maryland was provided by 14 associate degree programs on 15 community college campuses in 2004 (MBON, 2003). Graduates with an associate's degree of nursing (ADN) from Maryland community colleges are eligible to sit for the RN National Council Licensure Examination (MBON, 2003). In 2003, Maryland community colleges had 6,697 students enrolled in nursing programs (MHEC, 2003). Course work for nursing students typically includes liberal arts education and biological, physical, psychological and social sciences (MBON, 2003; NCSBN, 2004b). Associate degrees in nursing typically take between five to six semesters to complete and require between 65 to 70 credits of which 35 to 40 credits are in the field of nursing (MBON, 2003).

Although one of the primary purposes of the community college is to provide technical skills training, education in basic workplace competencies prepares nurses to acquire and integrate new knowledge within a complex, changing, and diverse working environment (USDHHS, 2001b). Basic workplace competencies needed by nurses include: (a) problem solving, (b) interpersonal and communication skills, (c) critical thinking, (d) relationship management, (e) information literacy, (f) sensitivity to diversity, (g) creativity, (h) teamwork 
skills, and (i) ethical decision making (AACN, 2002; Carnevale \& Desrochers, 2001; NLNAC, 2003). Accordingly, community colleges must develop curricular processes and outcomes that emphasize the attainment of these competencies. Nurses who demonstrate these competencies are highly sought after because they quickly adapt to the changing demands of a complex work environment of healthcare (Carnevale \& Desrochers, 2001; Carnevale, Gainer, \& Meltzer, 1990; Overtoom, 2000).

\section{The Changing Mission of the Community College}

From their birth in the early 1900’s, junior and later community colleges have changed to meet the needs of their communities. Cohen and Brawer (1996) attributes the growth of the community college to a constant demand put on schools by society to solve both social and personal problems. The role and mission of the community college has been expanded to now include “a broad array of educational, social, and economic functions” (Bailey \& Averianova, 1998, p. 1) based on the demands of the community in which the institution serves. In the area of workforce development, Cohen and Brawer (1996, p. 2) stated, “schools are expected to solve problems of unemployment by preparing students for jobs.”

The diversification of the community college mission has resulted in colleges segmenting themselves into functional units based on the needs of the population they serve. These units usually include transfer preparation, occupational-technical education (career education), continuing education, community service, and remedial education (Cohen \& Brawer, 1996). Cohen and Brawer (1996) wrote, “All have been present in public colleges from the start” (p. 21).

Each function of the community college has its advocates and critics. Many proponents of providing a transferable liberal arts education, or academic education, argue that the foundational mission of the community college is to provide academic studies that build 
cognitive development. They further argue that the pursuit of multiple missions has resulted in “mission creep,” a condition where the new missions receive the highest priority within the institution at the expense of the traditional functions. This group, also known as "instrumentalists and institutionalists,” suggest that community colleges have hindered the success of baccalaureate aspirations of students (Dougherty, 2001, p. 35).

Cohen and Brawer (1996) stated that the academic function serves several institutional purposes to include "a population function, a democratizing pursuit, and a function to conduct the lower division for the universities” (p. 21). Eaton (1993, ๆ 2) suggests that community colleges have played the role of a "democratizing institution." She stated that the role is the result of several visions. They were identified as the responsiveness, education-for-work, and the pre-baccalaureate education vision. She argued that community colleges have used all three visions to become democratizing institutions. She further argued that one of the fundamental ways for community colleges to meet the challenge of becoming a democratizing institution is through a renewed commitment to the collegiate role.

Community colleges are seen as the gateway institution for society. Community colleges serve as the primary source for access into higher education for members of the community that want to pursue education beyond high school. Community colleges provide an alternative access point other than four-year colleges and universities (Eaton, 1993). This policy is reflected by the different admission policies of each type of institution. In 1999-2000, 62\% of public community colleges had an open admissions policy, compared to 7.5\% of public 4-year colleges (NCES, 2002, Table 312, p. 356).

The literature pertaining to the role of occupational education in the community college shows two conflicting views on the occupational mission of the community college. The first view is that occupational education is an adjunct to the principle functions of the college, general 
and liberal education. The second view maintains that occupational education is an intrinsic quality that separates the community college from other forms of post-secondary education. This second view has several strong proponents, and received a very strong affirmation after WW II, when the occupational education mission of the community college increased in size and scope.

Cohen and Brawer (1996, p. 216) defined career education as "all curricula leading to employment.” The career education mission includes workforce preparation and career training given in both credit and non-credit courses. The scope of the career education programs of any particular community colleges depends on the occupational needs of the state or community. For example, community colleges in Maryland have responded to the need for workers in the area of information technology, teacher education, nursing/allied health, construction and tourism by developing statewide goals and objectives to fill the workforce shortage (Maryland Association of Community Colleges, 2001).

The need for occupational programs began in the early 1900's to fill the demand for auxiliary or support occupations of certain professional occupation groups (Cohen \& Brawer, 1996). Community colleges took on the role of training the semiprofessionals. In the 1970’s vocational-technical educational programs reached parity with the number of students enrolled in non-vocational-technical programs (Cohen \& Brawer, 1996). The U.S. Department of Education recently reported in their report entitled National Assessment of Vocational Education: Interim Report to Congress (2002, p. 65) that of the students that were pursuing a postsecondary credential-baccalaureate or sub-baccalaureate; over one-third were enrolled in occupational subbaccalaureate courses or programs.

Community colleges have had a long history of providing occupational and technical training. Recently that role has been expanding. For many students the community college is the last stop before they enter the workforce. States have recognized the need for occupational- 
technical education and have used the junior and community college system to meet this need. Laws such as the School-to-Work Opportunities Act (STWOA) and changes to the Carl D. Perkins Vocational and Applied Technology Education Amendments of 1998 legislated that community colleges take on a stronger role in the economic development of our country to address the nation's skills shortage by developing stronger connections between what is taught in school and what are the skills required in the workplace.

In most community colleges, the role of providing community education covers a wide variety of functions that serve the community. Cohen and Brawer (1996) identified the five functions as (a) adult education, (b) continuing education, (c) lifelong learning, (d) community services, and (e) community-based education. Adult education services are provided for adult students that do not follow the traditional longitudinal pathway through the educational system. Specifically these programs are designed for students that have attained their desired level of education or have had a lapse in the attainment of their education. Continuing education encompasses programs developed for students that want to continue their pursuit of knowledge. Typically people who desire to increase their knowledge, skills, and abilities that are then implemented in their work or personal life undertake this type of education. Cohen and Brawer (1996, p. 280) defined life long learning as “intermittent education, whether or not undertaken in school settings.” Community services are the services being offered to the community in which the institution serves. Community-based educational programs are developed by the community and offered to the community through the community college as a way to add value an/or to enhance the lives of citizens.

Community colleges are expected to provide services to those who come to them who are not prepared academically. The recent publication National Assessment of Vocational Education: Interim Report to Congress (2002, p. 71-72) reported that: 
1. Postsecondary vocational students tend to enter with low levels of academic achievement.

2. Postsecondary vocational students are somewhat less likely to have pursued a rigorous high school program.

3. Postsecondary vocational students report less remedial course taking than do academic students, probably because vocational programs have fewer academic requirements.

4. Few students who pursue a sub-baccalaureate vocational major already have a postsecondary credential.

Several college university systems have established policies redirecting students to community colleges who do not meet certain academic entrance criteria (Coley, 2000). Remedial programs have been shown to be effective in increasing the retention rates of students (Cohen \& Brawer, 1996). Remedial education consists of courses and programs designed to provide students who were poorly prepared by secondary institutions in basic skills such as basic reading, writing, and arithmetic, to function at a high level in our society. These programs are also called developmental, preparatory, or basis skills studies (Cohen \& Brawer, 1996).

Many states are under extreme pressure to reduce expenditures because of a reduction in state revenues as a result of the sluggish economy of the early 2000's. Higher education is one of the areas states have looked at as a source of budget cuts to reduce state expenditures. As budgetary pressures increase, discussions are made on campuses to determine which programs to fund and which ones to eliminate. The result has been a clash over the prioritization of missions within the institution. This has left many institutions examining their mission to determine both their primary scope and function. Colleges must balance their scope and function of the institution against the needs of their internal and external constituents. At the same time 
community college leadership is under increasing pressure to expand their missions and provide services to members of the community that face social and economic problems (Bailey \& Averianova, 1998).

The struggle over what the community college of the future will look like continues. Community colleges need to be ever vigilant in identifying trends which will affect the composition of the community college of the future with the goal of insuring that community colleges are efficient, relevant, and important to the community they serve (Cohen \& Brawer, 1996). Bailey and Averianova (1998) stated that community colleges needed to focus their efforts and integrate their diverse activities to reach their potential in the future. The Community College Role in Occupational Education

Over the last century community and junior colleges have had to shift their missions to reflect the changing nature of work and the rapid advance of technology. Some community college proponents believe that the traditional academic should be the core of the community college of the future. Others argue that community colleges are not doing enough to meet occupational, community service, and economic development needs. Employers and students look to community colleges to provide programs that provide skills training (Bailey \& Averianova, 1998).

Community colleges have broadened their economic development role over the last 20 years to fill the need of business in the knowledge economy for a high performance workforce. Recent reform initiatives such as the Tech Prep of the Vocational Education Act and more recently the School-to-Work Opportunities Act (STWOA) legislated that community colleges take on a stronger role in the economic development of our country (Grubb, 1994).

Dougherty (2001) argues that governmental initiatives are the leading cause for the growth of occupational programs in community colleges. He suggests that among the many 
advocates for the vocationalization of community colleges (including the labor market, private interest groups, community college and university heads, government actors, state departments, boards of education, congress members, and presidents), government officials have put their stamp on the vocationalization of the community college and "often promoted occupational education even in the absence of demand from students or business, and they did so on the basis of values and interests of their own” (Dougherty, 2001, p.195).

Legislation alone cannot sustain educational initiatives nor ensure quality educational programs. Participation and collaboration with local industries is the key to educational program sustainability and quality. Bragg and Hamm in their 1996 study of work-based learning programs in community colleges found that strong connections between work-based learning programs and their environment was an indicator of the quality of the work-based program.

One of the traditional missions of community colleges since its inception was to prepare members of the community to work in their communities. Community colleges play a critical role in workforce preparation. Cohen and Brawer (1996, p. 246) stated that communities view community colleges as "agents of upward mobility for individuals" and as the communities “occupational training center.” Community colleges have been involved in providing occupational education specifically in pre-service (pre-employment training) and in-service education (onsite customized training and on-the-job training). More recently that focus has expanded to include workforce preparation and economic development (Dougherty \& Bakia, 1999). They have been actively involved in providing pre-employment training to a wide variety of students. This group includes (a) students who have recently graduated from high school, (b) labor force re-entrants such as unemployed workers, (c) displaced homemakers, (d) welfare recipients, and (e) former prison inmates (Cohen \& Brawer, 1996; Grubb, 1996). Grubb (1996) found that of the students with sub-baccalaureate college education, $48 \%$ obtained training at a 
community college. Community colleges also serve as primary portals for certain professions such as nursing. A U.S. Census Bureau study reported that associate’s degree holders comprised 60\% of graduates in registered nursing in 1996 (U.S. Bureau of Census, 1998).

Students who graduate from community colleges' occupational programs receive substantially better wages than do those with only a high school degree (Grubb, 1996). The former earn $20 \%$ to $30 \%$ more than do the latter; they also average lifetime earnings of $\$ 250,000$ more than those without degrees (Phillippe \& Patton, 2000). Graduates receiving a degree from a community college outpaced the median earnings of high school graduates by 28\% in 2001 (U.S. Census Bureau, 2002). Students who have attended a community college but do not have a degree outpaced the median earnings of high school graduates by 19\% in 2002 (U.S. Census Bureau, 2002). Community college students find much better returns if they find employment in their field of study (Grubb, 1996).

The primary purpose of workforce development programs is to prepare students for employment through the development of knowledge, skills, and abilities that are required by the workplace. Workforce development curricula are developed by college staff after the monitoring employment trends and employer workforce education needs. After a need for workforce education is uncovered, the college will usually assign a program coordinator to develop the program. Program coordinators typically work with local workforce advisory boards made up of representatives from business and industry (Cohen \& Brawer, 1996). Workforce advisory boards meet periodically with the college. Workforce advisory boards are a resource to determine the specific knowledge, skills and abilities needed in a specific industry.

Determining what is a successful workforce development program is subjective. Typically colleges monitor the placement rate and first salary earned of workforce development programs as an indicator of program success. Each program must be evaluated based on its 
features and the students enrolled (Cohen Brawer, 1996). Cohen and Brawer (1996) further suggests that the success of workforce development training depends on what you measuring. Although many workforce development programs are designed to prepare students for a specific career, many students are enrolled in workforce development training for other reasons such as to upgrade their current skills for a position they have already held (Cohen \& Brawer, 1996, p. 233).

\section{Workplace Competencies Defined}

Until 1990, the question of which skills are most essential for effective work performance was answered through independently developed lists of skills. The result was separate lists that led to confusion in the minds of educators, students, and business leaders over the operational implications and meanings of the lists. These lists also lacked context. Two national reports, one by the American Society for Training and Development (ASTD; Carnevale \& Johnston, 1989) and one by the Secretary's Commission on Achieving Necessary Skills (SCANS; USDOL, 1991b) are considered foundational works in identifying employability skills, and are often used as benchmarks or beginning points for other international, national, state, regional, and local studies (Overtoom, 2000).

The Carnevale and Johnson (1989) report outlined background information and provided recommendations to improve job related learning in the United States. The report represented a call to action for employers, educators, and legislators to take a stronger stand in promoting a basic workforce competency agenda. The report outlined the "learning deficit," a situation created when the need for high performance workers exceeds the supply (ASTD, 1989, p. 6). The report recommended that employers, educators, and legislators work to develop a comprehensive strategy to fill the learning deficit. 
In order to eliminate confusion over the multiple lists, former U.S. Secretary of Labor Lynn Martin requested a study of the workplace to identify necessary work competencies. The result was the formation of The Secretary's Commission on Achieving Necessary Skills (SCANS) in 1990. The goal of the commission was to identify those competencies, skills and personal qualities required by employees to work in the high-performance workplace. It was thought that by identifying these competencies, a coordinated effort could begin to incorporate the skills into the educational system to develop a high skilled workforce, which would be able to produce high value goods and services resulting in high wage employment. The SCANS released several publications that outlined the competencies needed by workers to develop and produce products and services that demand a premium in the global marketplace.

The U.S. Department of Labor (1991b) SCANS report identified five competencies and a three-part foundation of skills and personal qualities that are needed for job performance in a high performance workplace. The five competencies consisted of a list of abilities employers identified as being essential to be able to work efficiently in the every changing environment of the modern workplace. The five competencies an employee must be able to use are resources, interpersonal skills, information, systems, and technology. The report further defined each competency (USDOL, 1991b, p. 11):

1. Resources: Workers schedule time, budget funds, arrange space, or assign staff.

2. Interpersonal Skills: Competent employees are skilled team members and teachers of new workers; they serve clients directly and persuade co-workers either individually or in groups; they negotiate with others to solve problems or reach decisions; they work comfortably with colleagues from diverse backgrounds; and they responsibly challenge existing procedures and policies. 
3. Information: Workers are expected to identify, assimilate, and integrate information from diverse sources; they prepare, maintain, and interpret quantitative and qualitative records; they convert information from one form to another and are comfortable conveying information, orally and in writing, as the need arises.

4. Systems: Workers should understand their own work in the context of the work of those around them; they understand how parts of systems are connected, anticipate consequences, and monitor and correct their own performance; they can identify trends and anomalies in system performance, integrate multiple displays of data, and link symbols (e.g., displays on a computer screen) with real phenomena (e.g., machine performance).

5. Technology: Technology today is everywhere, demanding high levels of competence in selecting and using appropriate technology, visualizing operations, using technology to monitor tasks, and maintaining and troubleshooting complex equipment.

The U.S. Department of Labor (1991b, p. xi) report further explained that the three foundational skills were embedded in each of the five competencies. Proficiently in each of the foundational skills are necessary to obtain competent performance in each of the five competencies. The foundational skills are creative and analytic skills that allow an employee to solve problems and make decisions in the workplace (USDOL, 1991a). The report further defined each of the foundational skills (USDOL, 1991b, p. 13):

1. Basic Skills: Reading, writing, mathematics (arithmetical computation and mathematical reasoning), listening, and speaking;

2. Thinking Skills: Creative thinking, making decisions, solving problems, seeing things in the mind's eye, knowing how to learn, and reasoning; and 
3. Personal Qualities: Individual responsibility as well as self-esteem, sociability, selfmanagement, and integrity.

\section{Research of Workplace Competencies}

Subsequent updates to the original SCANS documents were published to include: (a) American and the New Economy (Carnevale, 1991), (b) Learning and Living: A Blueprint for High Performance (USDOL, 1992), (c) Skills for industrial modernization (Russell \& Coffey, 1993), (d) The Mindful Worker: Learning and Working into the $21^{\text {st }}$ Century (Miles, 1994), and (e) Skills and Tasks for Jobs (USDOL, 1992b). The updates included the same list of characteristics as stated in the SCANS reports and contained similar lists of characteristics contained in the previously published works of Carnevale and Johnston (1989), Carnevale, Gainer, and Meltzer (1990), the Commission on the Skills of the American Workforce (1990), and the National Council for Occupational Education (1990). In addition to national initiatives, several states researched studies to assess workplace competencies to include Michigan (Mehrens, 1989), New York (New York State Education Department, 1990), Florida (Florida Department of Education, 1995), and Maryland (Maryland State Department of Education 1996).

Recent research conducted by Ivey (2002) sought to determine the level of attainment of workplace competencies (SCANS skills) by applicants as perceived by human resource personnel. Data were collected data from face-to-face interviews with human resource personnel. The researcher found that the human resource personnel were having a difficult time finding qualified employees. The author presented several causes for this finding: (a) a decline in work ethic, (b) fewer applicants, and (c) the applicant’s level of soft skills (Ivey, 2002, p. 80). On a positive note, the research found that as the education level of the applicant increased, so did their level of workplace competencies (Ivey, 2002, p. 81). 


\section{Workplace Competencies Skills Gap in Nursing Education}

Nurses are not adequately prepared to provide medical care in the changing healthcare environment (National Academy of Sciences, 2003). Educational institutions have not adapted their curriculum to reflect the attainment of core competencies required to provide high quality and safe healthcare (National Academy of Sciences, 2003). Nurses of the future will need to possess skills beyond what is currently being taught in Associate Degree Programs (Pew Health Professions Commissions, 1998). Workplace competencies such as problem solving, interpersonal and communication skills, critical thinking, relationship management, information literacy, sensitivity to diversity, creativity, teamwork skills, and ethical decision making need to be added to the traditional nurse competencies taught in nursing programs (Pew Health Professions Commissions, 1998). These skills help the nurse to adapt the changing healthcare environment.

There is also a shortage in the level attainment of required workplace competencies by nurses in the workforce (USDHHS, 2001b). The majority (57\%) of the nurses employed nationwide in 2000 received their basic nursing education before 1985 (USDHHS, 2001b). This trend is similar in Maryland with the majority (75\%) of nurses having over 15 years of nursing experience (MBON, 2002). This fact coupled with the rapid changes in healthcare has created a gap between the skills required by nurses in the workplace and the skills taught in nursing programs. Nurses currently in the workplace need to upgrade their basic workplace competency skills to operate in the ever changing work environment (USDHHS, 2001b).

\section{Work-Based Learning Defined}

Many words have been used to define work-based learning to include: (a) job shadowing, (b) externships, (c) apprenticeships, (d) school-to-work, (e) field studies, (f) practicum’s, (g) 
independent studies, and (h) internships (Wilson, Stull, \& Vinsonhaler, 1997). Bragg, Hamm, and Trinkle (1995, p. iii-iv) defined work-based learning as:

... instructional programs that deliberately use the workplace as a site for student learning. WBL programs are formal, structured, and strategically organized by instructional staff, employers, and sometimes other groups to link learning in the workplace to students' college-based learning experiences. WBL programs have formal instructional plans that directly relate students' WBL activities to their career goals. These WBL experiences are usually but not always college-credit generating.

Work-based learning (WBL) is not a new concept. Cooperative education, a type of work-based education, was first recognized by the federal government in the 1917 Smith Hughes Act (Stasz \& Stern, 1999). WBL serves five main purposes in education: (a) enhancing students' motivation and academic achievement; increasing personal and social competence related to work in general, (b) gaining a broad understanding of an occupation or industry, (c) providing career exploration and planning, (d) acquiring knowledge or skill related to employment in particular occupations or more generic work competencies, and (e) enhancing students' motivation and academic achievement (Urquiola et al., 1997).

Stasz \& Stern (1999, p. 9) determined that recent interest in WBL had developed because of three factors:

... federal legislation (especially, the 1990 Amendments to the Carl Perkins Act, and the School-to-Work Opportunities Act of 1994); research studies that found improvement in learning when situated in a context that lends it meaning and motivation; and changes in the nature of work which suggest a growing demand for continued learning and problemsolving in the workplace. 
Bragg, Hamm, and Trinkle (1995) also identified the School-to-Work Opportunities Act (STWOA) as a catalyst for change for WBL. Bragg, Hamm, and Trinkle (1995) stated that it was the School-to-Work Opportunities Act (STWOA) which propelled work-based learning as a tool for educational reform. The goal of the STWOA was to improve the quality of teaching and learning in the classroom and the workplace through the use of a national framework. This framework was intended to act as a catalyst on the state and local level to implement school-towork systems (Bragg, Hamm, \& Trinkle, 1995). No one model was endorsed by the STWOA, but states were encouraged to explore work-based learning approaches as ways to assist in successful transition from school-to-work (Bragg, Hamm, \& Trinkle, 1995).

Community colleges have played a particularly strong role in providing work-based learning. The STWOA was enacted to strengthen the relationship between occupational and academic education, educators and employers, and secondary and postsecondary education (Bragg, Hamm, \& Trinkle, 1995). The school-to-work system consisted of three components and forms the foundation of the educational system. Bragg et al. (1995) lists the components as a work-based component, a school-based component, and a connecting component. Work-based learning activities are designed to promote learning by linking the world of work to the world of school (Stasz \& Stern, 1999) and allow students to “acquire progressively higher-level skills” (Bragg, Hamm, \& Trinkle, 1995, p. 3).

The definition of internship is subjective. What one calls an internship another might call a cooperative educational experience. In fact, Ryder (1987, p. 3) stated, "It is entirely possible that on a single campus one may find a listing for both cooperative education and internships and hardly recognize the difference between the two.” He further noted that internships and cooperative education look very much alike with the difference being that internships are single 
experiences or last for a single term. In contrast, cooperative educational experience usually spans more than one term (Ryder, 1987).

The National Society for Experiential Education (NSSE, 1998, ๆ 1) further defines an internship as “Any carefully monitored work or service experience in which an individual has intentional learning goals and reflects actively on what she or he is learning throughout the experience.” The learning goals may include (a) academic learning, (b) career development, (c) skill development, and (d) personal development. They further clarified that:

Internships vary in duration; they can last from a month (or less) to two years (or more). They can take place in any work or service setting. Interns may be senior citizens, eighth graders, college students, mid-career executives, career changers, graduate students, adult learners, or people anywhere in between. Internships can be part-time or full-time, paid or unpaid. They may be part of an educational program and carefully monitored and evaluated for academic credit. Or, they can be part of a learning plan that the intern develops. The important element that distinguishes an internship from a short-term job or community service is the intentional "learning agenda" that the intern brings to the experience (NSEE, 1998, ๆ 2-4).

The research related to work-based learning has been done mostly in the field of cooperative education. The benefits for students who have been enrolled in work-based learning like cooperative education are well documented. Researchers have documented the long-term effects of work-based learning experiences for students. Specifically, Van Gyn, Cutt, Lonken, and Ricks (1997) conducted a longitudinal study investigating the educational benefits of cooperative education. This research was conducted to counter criticism by some researchers that questioned the educational benefit of cooperative education and the validity of previous research. 
Critics have pointed to the descriptive nature and methodological problems related to previous research (Van Gyn et al. 1997).

Van Gyn, Cutt, Lonken, and Ricks (1997) conducted their own research on the outcomes attained by students engaged in cooperative education experiences and found that students who participated in cooperative education showed a significantly better performance on the College Outcomes Measure Program (COMP) exam by the American College Testing Program (ACT) than did students who did not participate in a cooperative education work experience program (Van Gyn, Cutt, Lonken, \& Ricks, 1997). The COMP exam is designed to measure the ability to apply general knowledge and skills to functioning in society (Van Gyn et al. 1997). The students enrolled in a cooperative education showed the greatest benefit of participation in the areas of problem solving and functioning in a social institution.

A similar study was conducted by Eyler (1994) looked at the impact of two internships experiences on student learning. The researcher found that the internship experience contributed to a breakdown of a barrier that allowed the transfer knowledge and experience. Work-based Learning in Nursing Education Programs

Nursing education programs at community colleges typically include a work-based learning clinical experience (Bragg, Hamm, \& Trinkle, 1995). This experience is designed to provide the student with an opportunity to apply skills learned in the classroom in a real-life setting. It is also a time when the student can learn new skills not taught in the classroom. Bragg, Hamm, and Trinkle (1995, p. 32) defined a work-based learning clinical experience as "Work site learning that occurs in association with preparation for a credential in a professional health care field.” They found nursing programs are the most likely program within the community college to have work-based learning as part of its curriculum. Bragg, Hamm, and Trinkle (1995) sought to ascertain which work-based learning models were being utilized in two-year colleges. 
Colleges were asked to choose which work-based learning model best fit their program. The researchers found that $97 \%$ of the health work-based learning programs used the model of clinical experience. In contrast, 64\% of the non-health programs used the cooperative education model. They further found that over $90 \%$ of the respondents indicated similarities in the components of their clinical experience programs. Similarities included (a) periodic evaluation, (b) coordinated classroom and workplace learning, (c) formal contracts or cooperative agreements with partners, (d) formal assessment and certification of skills based on industry standards, (e) integrated occupational-technical academic instruction, and (f) formal programs of career awareness, orientation, and guidance.

\section{Characteristics of Exemplary Work-based Learning Programs}

Bragg and Hamm (1996) in their study sought to determine the exemplary policies and procedures of two-year college work-based learning programs. The researchers investigated the quality of the work-based learning programs from the views of students, faculty, and employers (Bragg \& Hamm, 1996). The study resulted in a list of factors that contribute to the overall effectiveness of two-year college work-based learning programs. Bragg and Hamm (1996) listed the factors as (a) strong program leadership, (b) exclusive connections between the program and its environment, (c) frequent and effective communications with local employers, (d) beliefs about program excellence, (e) a program with effective school-based learning component, (f) adequate and diverse financial support, and (g) innovative program and pedagogical features.

Strong program leadership is a critical factor in determining the effectiveness of workbased learning programs. Bragg and Hamm (1996) found that schools with exemplary policies and practices had strong program leadership. In most schools the responsibility of leading workbased learning lies with either an individual or a small group (Bragg \& Hamm, 1996). They also found that program leaders were involved in daily program operations. Program leadership is 
especially important during the beginning stages of a new work-based learning program (Bragg \& Hamm, 1996).

Having an exclusive connection between the program and its environment was another critical factor cited by Bragg and Hamm (1996). They found that programs had an exclusive connection to its environment if the program: (a) was either the only one in a market or the competitive leader, (b) had strong connections between important community industries and their work-based learning programs, and (c) was considered to have an economic impact on the community because of the work-based learning program provided the industries with highlyskilled employee.

Frequent and effective communications with local leaders was another factor cited by Bragg and Hamm (1996) as being essential to work-based learning program success. They cited frequent and routine formal communications (e.g. regular meetings) and informal communications (e.g. work site visits) by work-based learning staff with industry personnel as being essential part a successful work-based learning program. Specifically, they reported that as the frequency of work site visits increased by the work-based learning staff, the relationship between the work-based learning program and industry improved.

Colleges with exemplary policies and procedures were able to identify positive common beliefs held by the college and community about the work-based learning programs excellence (Bragg \& Hamm, 1996). Schools were this belief was present did not have a problem recruiting students for work-based learning programs. The researchers found that during their site visits, schools with a strong positive reputation for providing work-based learning provided examples of common beliefs which included: “The programs were 'the best' programs; that the programs achieved a high-level of excellence; that program completers were of especially high quality and 
thereby supporting industry; and that competing programs were inferior” (Bragg \& Hamm, 1996, p. 44).

Having an effective school-based learning component was identified as being a critical by Bragg and Hamm (1996). Colleges that sustained strong relationships between the work-based learning programs and other parts of the college in turn were better supported by the college (Bragg \& Hamm, 1996). This support lead to the accessibility of resources such as dedicated space for classrooms and labs needed for the school-based learning component of some workbased learning experience such as cooperative education.

The ability to obtain adequate financial support was another critical factor identified by Bragg and Hamm (1996). It is imperative that schools have a steady and adequate supply of financial resources to maintain work-based learning programs (Bragg \& Hamm, 1996). Several schools identified as having exemplary policies and procedures by Bragg and Hamm (1996) reported that they had several sources of financial resources (e.g., local government, state government, federal government, local industry). Continual financial support allows schools to strategically plan the growth and development of work-based learning programs (Bragg \& Hamm, 1996).

Several strategies were identified by Bragg and Hamm (1996) as being innovative program and pedagogical features of two-year college work-based learning programs. These included (a) developing creative structured individualized plans for student success, (b) establishing an effective mentoring system, (c) implementing articulation agreements from the secondary to the two-year college and to the four-year college levels, (d) providing program flexibility and adaptability, (e) mixing work-based learning models and pedagogical approaches, and (f) encouraging personalized documentation combined with the standardized performancebased competency profiles. The presence of these innovative and pedagogical characteristics 
provides proof to skeptics that work-based learning programs are academically demanding as well as being practical and applied (Bragg \& Hamm, 1996).

Conceptual Framework

The overarching conceptual framework for this study is illustrated in Figure 1 (see page 34). The conceptual framework consists of six parts: (a) student demographics, (b) exemplary policies and practices of work-based learning programs, (c) pre-test of the Working: Assessing Skills, Habits, and Style assessment instrument, (d) the clinical experience, (e) post-test of the Working: Assessing Skills, Habits, and Style assessment instrument, and (f) the level of attainment of workplace competencies.

The student enters the work-based learning experience with certain attributes. These attributes form a demographic picture of the student. Student demographic characteristics such as (a) age, (b) previous work experience, and (c) academic achievement provides a framework from which the student interprets the work-based learning experience.

A pre/post-test self-assessment questionnaire developed for H\&H Publishing Company, Inc. by Miles and Grummon (1996) was administered to the student before and after their clinical experience. The instrument is entitled Working: Assessing Skills, Habits, and Style. It is designed to assess nine key workplace competencies including taking responsibility, working in teams, persisting, a sense of quality, life-long learning, adapting to change, permanent problem solving, information processing, and systems thinking. The instrument consists of 50 questions. Each question is correlated to one of the nine-workplace competencies.

Clinical experiences are defined as: "Work site learning that occurs in association with preparation for a credential in a professional health care field” (Bragg, Hamm, \& Trinkle, 1995, p. 32). The Bragg and Hamm (1996) study resulted in a list of factors that contribute to the overall effectiveness of two-year college work-based learning programs. This conceptual 
framework applies the concepts of Bragg and Hamm's study of exemplary policies and practices of two-year college work-based learning programs to the attainment of workplace competencies. The purpose of the study was to answer the following questions:

1. What types of gains do students who participate in nursing clinical experiences demonstrate over time?

2. Are there significant differences in workforce competencies between students enrolled in nursing clinical experiences at community colleges that reflect exemplary policies and procedures versus students at community colleges that do not reflect exemplary policies and procedures?

3. Are there significant differences in workforce competencies for students by various demographic factors and institutional variables? These factors include previous work experience, age, academic achievement, and the number of credits the student will be awarded for the completion of the clinical experience. Selected institutional variables include institutional size and the size of an institutions associate degree of nursing program; that is the number of students enrolled in the institutions associate degree of nursing program. 
Figure 1. Conceptual Framework.

Student Demographics, Exemplary Policies and Practices of Work-Based Learning Programs, the Clinical Experience, Pre/Post Test, and Level of Attainment of Workplace Competencies

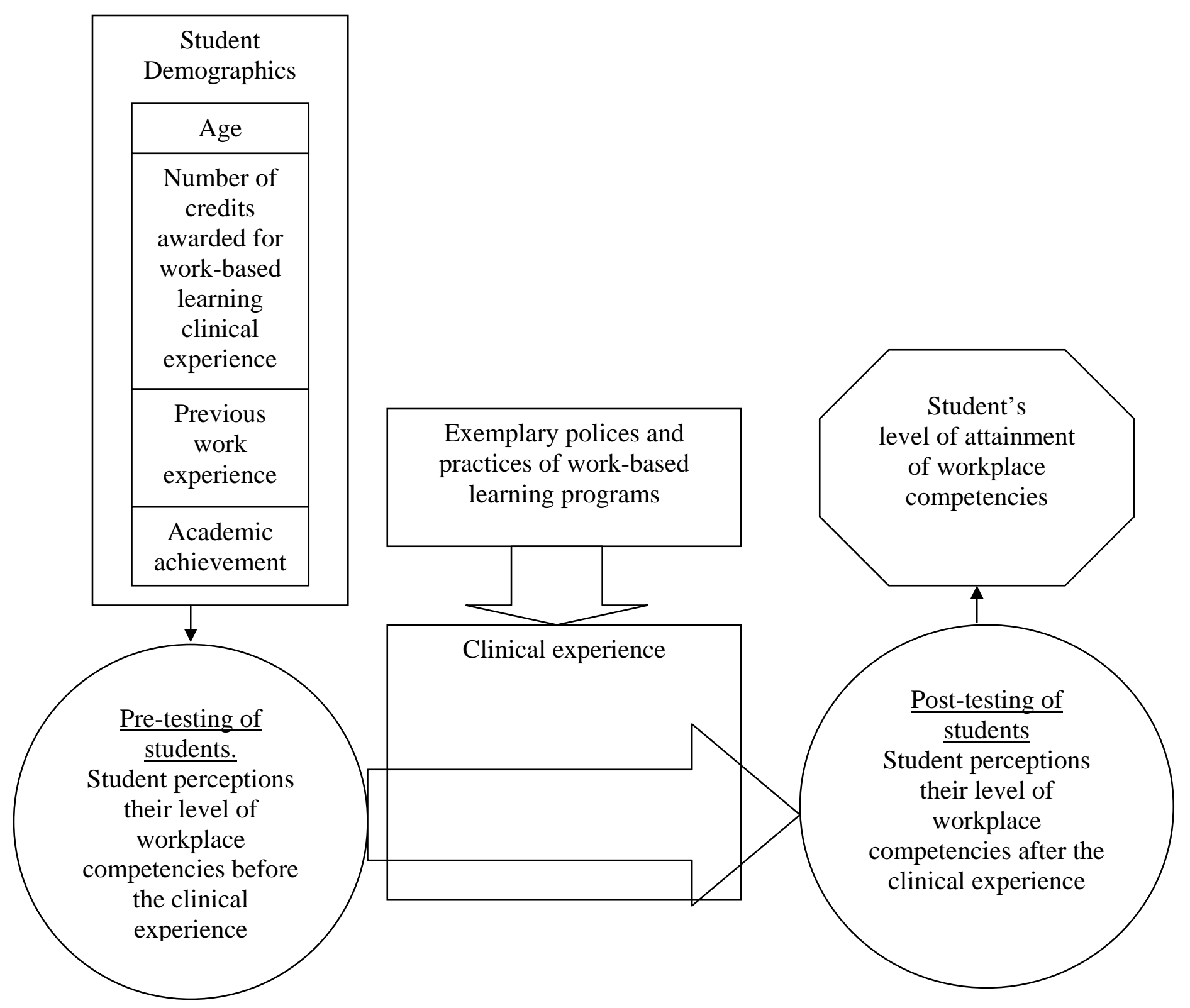




\section{Chapter Three}

Method and Research Design

\section{Introduction}

This intervention and associational study (Frankel \& Wallen, 2000) used a survey approach to gather data to answer the research questions. Frankel and Wallen (2000, p. 17) defined intervention studies as those where "a particular method or treatment is expected to influence one or more outcomes.” In this study the treatment is the clinical experience and the outcome (net gain/loss in student scores from the Working: Assessing Skills, Habits, and Style questionnaire) was hypothesized to be influenced by the student's demographic characteristics as well as the policies and practices of the nursing program at each community college.

Data was collected from questionnaires distributed to Maryland community college students who participated in a nursing work-based learning clinical experience during the fall 2004 semester. The purpose of the study was to answer the following questions:

1. What types of gains do students who participate in nursing clinical experiences demonstrate over time?

2. Are there significant differences in workforce competencies between students enrolled in nursing clinical experiences at community colleges that reflect exemplary policies and procedures versus students at community colleges that do not reflect exemplary policies and procedures?

3. Are there significant differences in workforce competencies for students by various demographic factors and institutional variables? These factors include previous work experience, age, academic achievement, and the number of credits the student will be awarded for the completion of the clinical experience. Selected institutional variables include institutional size and the size of an institutions associate degree of nursing 
program; that is the number of students enrolled in the institutions associate degree of nursing program.

\section{Survey Instruments}

Format and General Construction

The study utilized five questionnaires for data collection: a nursing program coordinator interview questionnaire (see Appendix A), work-based learning program dimensions questionnaire to the nursing program coordinator (see Appendix C), a pre-clinical experience student demographic characteristic questionnaire (see Appendix E), a post-clinical abbreviated student questionnaire (see Appendix G), and the Working: Assessing Skills, Habits, and Style questionnaire (see Appendix H). The instruments were utilized during the five phases of data collection. The following table (see Table 1) is a summary of the instruments used in this research, which appendix the instrument appears in, and the respondents to each instrument. Table 1

Instruments, Appendix, and Respondents

\begin{tabular}{|c|c|c|c|}
\hline & Instrument & Appendix & Respondent \\
\hline \multirow[t]{2}{*}{1.} & Nursing program coordinator & A & Nursing program coordinator \\
\hline & interview questionnaire & & \\
\hline \multirow[t]{2}{*}{2.} & Work-based learning program & $\mathrm{C}$ & Nursing program coordinator \\
\hline & dimensions questionnaire & & \\
\hline \multirow[t]{2}{*}{3.} & Pre-clinical experience student & E & Nursing student \\
\hline & demographic characteristic questionnaire & & \\
\hline \multirow{3}{*}{$\begin{array}{l}4 . \\
5 .\end{array}$} & Post-clinical abbreviated student questionnaire & G & Nursing student \\
\hline & Working: Assessing Skills, Habits, & & \\
\hline & and Style questionnaire & $\mathrm{H}$ & Nursing student \\
\hline
\end{tabular}


The nursing program coordinator interview questionnaire was designed to determine the interest of an institution to participate in this study and select variable data about the institution and the nursing degree program. It was given to nursing program coordinators at the beginning of this study.

The work-based learning program dimensions questionnaire was designed to collect data from associate degree of nursing students to determine to what extent a nursing work-based learning program reflects exemplary policies and practices as stated by Bragg and Hamm (1996). The questionnaire had a four point Likert ordinal scale for respondents to rate their agreement on how well the presented statement described the characteristics of the school's work-based learning program. The highest level of agreement was indicated by the response "strongly agree.”

The pre-clinical experience student demographic characteristic questionnaire consisted of multiple choice and short answer questions. This questionnaire was designed to collect data from the community college students participating in nursing clinical experiences. Information collected on the questionnaire included: (a) students name, (b) community college, (c) previous work experience, (d) age, (e) academic achievement level, (f) the number of credits the student were awarded for the completion of the clinical experience, and (g) the total number of hours required at the work-site to complete the clinical experience. The pre-clinical experience student demographic characteristic questionnaire was administered at the same time and to the same students as the pre-clinical administration of the Working: Assessing Skills, Habits, and Style questionnaire. Both the pre-clinical experience student demographic characteristic questionnaire and the Working: Assessing Skills, Habits, and Style questionnaire were coded to identify the student, the phase of the study, and the college where the student was enrolled. 
The post-clinical experience abbreviated student questionnaire asked the students for their name and community college name. This questionnaire was administered at the same time and to the same students as the post-clinical administration of the Working: Assessing Skills, Habits, and Style questionnaire. Both questionnaires were coded to identify the student, the phase of the study, and the college where the student was enrolled.

The Working: Assessing Skills, Habits, and Style questionnaire is a self-assessment questionnaire developed for H\&H Publishing Company, Inc. by Miles and Grummon (1996). The instrument is designed to assess nine key workplace competencies. The competencies measured by this study included (a) life-long learning, (b) permanent problem solving, (c) systems thinking, (d) a sense of quality, (e) taking responsibility, (f) information processing, (g) persisting, (h) adapting to change, and (i) working in teams. Every question had a five-point Likert-type scale for respondents to rate their agreement with how well the presented statement describes them. The highest level of agreement was "almost always like me" and equals five points. The lowest level of agreement was "almost never like me" and equals one point. No neutral response choices were provided in order to eliminate noncommittal responses. Each question on The Working: Assessing Skills, Habits, and Style questionnaire was correlated to a competency. The competency score for each student was determined by combining the responses from each question that correlated to a specific competency. The minimum and maximum score attainable on The Working: Assessing Skills, Habits, and Style questionnaire varied by workplace competency (see Table 2). If the student chose not to answer all questions related to a specific competency on either the pre-clinical or post-clinical of the Working: Assessing Skills, Habits, and Style questionnaire, a competency score was not calculated for that specific competency and the competency was not included in the analysis. 
Table 2

Minimum and Maximum Workplace Competency Scores Attainable on the Working: Assessing Skills, Habits, and Style Questionnaire by Workplace Competency

\begin{tabular}{lccc}
\hline \multicolumn{1}{c}{ Workplace Competency } & Item Numbers & Minimum Score & Maximum Score \\
\hline WC1 Life-long Learning & $6,16,23,33,40,48$ & 6 & 30 \\
WC2 Permanent Problem Solving & $8,17,28,41$ & 4 & 20 \\
WC3 Systems Thinking & $11,19,26,42$ & 4 & 30 \\
WC4 As a Sense of Quality & $2,14,27,35,43,50$ & 6 & 30 \\
WC5 Taking Responsibility & $3,13,21,30,37,44$ & 6 & 30 \\
WC6 Information Processing & $5,12,18,25,34,45$ & 6 & 30 \\
WC7 Persisting & $7,15,24,31,38,46$ & 6 & 30 \\
WC8 Adapting to Change & $1,10,20,29,36,50$ & 6 & 6 \\
WC9 Working in Teams & $4,9,22,32,39,49$ & 6 & 30 \\
\hline
\end{tabular}

Fifteen of the questions were reversed scored. The reversed questions were 1, 4, 6, 10, 16, 20, 21, 29, 36, 38, 40, 43, 44, 49, and 50. Permission was given to use and reproduce the Working: Assessing Skills, Habits, and Style self-assessment questionnaire by the author (see Appendix I).

Validity and Reliability

In the fall of 1995, Working: Assessing Skills, Habits, and Style was field-tested. Thirteen institutions from eleven different states participated in the field test. The institutions represented rural, suburban, and urban areas. Of the participating sites, nine were community colleges, two were technical colleges and two were state universities (Maduschke \& Grummon, 1996). 
Reliability

Maduschke and Grummon (1996) reported that Working: Assessing Skills, Habits, and Style was analyzed to determine if the scales contributed to the reliability of their assigned construct. The reliability analysis of the scales resulted in alpha coefficients ranging from 0.52 to 0.75 indicating sufficient reliability.

Validity

To assure content validity of the Working: Assessing Skills, Habits, and Style instrument, Maduschke and Grummon (1996) looked at the relationship between teachers’ and students’ perceptions of their skills, students level of experience and their responses on Working: Assessing Skills, Habits, and Style. They found that the teachers' perception of student's strengths and weaknesses on Working: Assessing Skills, Habits, and Style were especially comparable. This provided evidence that Working: Assessing Skills, Habits, and Style resulted in responses from students that were supported by the student's own experiences with work and school. They further looked at the correlation between students' level of experience and their responses on Working: Assessing Skills, Habits, and Style. Working: Assessing Skills, Habits, and Style. This analysis demonstrated convergent validity with correlation to all scales except teamwork. The lack of correlation of teamwork was a result of the skill of teamwork being used unevenly in work settings. The authors also compared the student's grade point averages (GPA) to their responses on the assessment. Maduschke and Grummon (1996) found that GPA was significantly correlated with six of the nine scales that directly associated with most of the student's school experiences. Working in teams, adapting to change, and systems thinking did not show significant correlation to the student's GPA as these skills are not typically taught in school. 


\section{Population Studied}

This study examined whether community college students who participated in nursing work-based learning clinical experiences developed basic workplace competencies necessary to work effectively in the workplace. The population studied was Maryland community college students pursuing an associate degree in nursing who were enrolled in their first work-based learning clinical experience. This population consisted of 618 students within eight community college associate degree of nursing programs resulting in a participation rate of $42.7 \%$.

Site Selection

The work-based learning program dimensions instrument was distributed to community colleges in Maryland with nursing programs. Entry-level registered nurse (RN) education in Maryland was provided by 14 associate degree programs on 15 community college campuses in 2004 (MBON, 2003). For the purposes of this study, community colleges were defined as public institutions that offered, “associate's degree and certificate programs but, with few exceptions, award no baccalaureate degrees. This group included institutions where, during the period studied, bachelor's degrees represented less than 10 percent of all undergraduate awards”(The Carnegie Foundation for the Advancement of Teaching, 2000, ๆ 9). A phone survey was conducted prior to the beginning of data collection to determine initial interest in becoming a site for data collection. Eight sites agreed to participate in the study.

\section{Data Collection}

Phase one consisted of determining which community colleges were interested in participating in the study. If a school was interested in participating in the study, information was collected by the researcher about the nursing program and the participating institution on the nursing program coordinator interview questionnaire. A phone survey was also conducted prior to the beginning of data collection to determine initial interest in becoming a site for data 
collection. Follow up communications were conducted by phone to obtain institutional information and nursing program information.

Phase two of the study consisted of mailing the nursing program coordinator pre-clinical experience cover letter (see Appendix B) and the work-based learning program dimensions questionnaire to nursing program coordinators at public community colleges in the Maryland that have agreed to participate in this study. Follow up communications were conducted by phone and mailed one week after the initial mailing to ensure greater participation in this phase of the study. Community colleges with nursing work-based learning clinical experiences were selected based on receiving approval from the individual program coordinator and confirmation that there will be students enrolled in their nursing clinical experience in the fall 2004 semester.

Phase three of the study consisted of the researcher conducting a pilot study using the student information and consent form (see Appendix D), the pre-clinical experience student demographic characteristic questionnaire, and the Working: Assessing Skills, Habits, and Style questionnaire. The pilot study was conducted during the summer of 2004 at a community college in Maryland. The pilot study was conducted on eight nursing degree students to determine whether respondents experience any problems and have any suggestions about the process. The pilot study provided a better gauge about the actual times required to complete the instruments. The only changes suggested by the pilot study participants were minor editorial changes to the Working: Assessing Skills, Habits, and Style questionnaire.

The fourth phase of the research consisted of the researcher visiting participating nursing degree program courses to solicit students to participate in this study. The researcher read aloud the student information and consent form to the students inviting them to participate in the study and the questionnaire directions. Students electing to participate in this study were asked to sign the student information and consent form and were administered the pre-clinical experience 
student demographic characteristic questionnaire and the Working: Assessing Skills, Habits, and Style questionnaire. This phase was conducted in late August or early September before the nursing degree students began their clinical experiences. At the end of this phase the researcher collected the student information and consent form, the pre-clinical experience student demographic characteristic questionnaire, and the Working: Assessing Skills, Habits, and Style questionnaire from the students.

The fifth and final phase of data collection consisted of the students that participated in the previous phase of data collection being given the post-clinical experience student cover letter (see Appendix F), and being administered the post-clinical experience abbreviated student questionnaire and the Working: Assessing Skills, Habits, And Style. Before the questionnaires were administered the researcher read aloud the questionnaire directions and the post-clinical experience cover letter to the students inviting them to participate in the study. This phase was implemented after the completion of the student's clinical experience in November and December, 2004. This phase needed to be completed within two weeks of the student completing their clinical experience. Once the final phase was completed, the cover letter for the Working: Assessing Skills, Habits, and Style questionnaire and the Working: Assessing Skills, Habits, and Style post-clinical experience questionnaire were collected by the investigator of the study.

\section{Data Analysis}

Independent and dependent $t$ tests and Analysis of Variance (ANOVA) was conduced to address each of research questions. Descriptive statistics are reported. The statistical software package SPSS (11.0) was used to analyze the data. Results were considered statistically significant at the .05 level.

The following table (see Table 3) is a summary of data that was used to address the research questions. 
Table 3

Data that was used for Evaluating the Research Questions

\begin{tabular}{lllc}
\hline \multicolumn{1}{c}{ Sources of Data } & Q1 & Q2 & Q3 \\
\hline 1. Nursing program coordinator & & & \\
$\quad$ interview questionnaire & & & \\
2. Work-based learning program & & & \\
$\quad$ dimensions questionnaire & & & + \\
3. Pre-clinical experience student & + & & + \\
$\quad$ demographic characteristic questionnaire & & & + \\
4. Working: Assessing Skills, Habits, & + & + & + \\
and Style questionnaire & & +
\end{tabular}

An explanation of the data and analysis used for each question is as follows:

Question 1 (Q1):

What types of gains do students who participate in nursing clinical experiences demonstrate over time?

This question was answered by analyzing data from the Working: Assessing Skills, Habits, and Style questionnaire (pre-clinical experience) and the Working: Assessing Skills, Habits, and Style questionnaire (post-clinical experience). The mean scores from the Working: Assessing Skills, Habits, and Style questionnaire (pre-clinical experience) and the Working: Assessing Skills, Habits, and Style questionnaire (post-clinical experience) were reported by workplace competency. A paired-samples $t$ test was conduced to compare the means scores gleaned from each of the nine key workplace competencies to determine if there are any significant differences. Students needed to answer all questions associated with a competency. If the student chose not to answer all questions related to a specific competency on either the pre- 
clinical or post-clinical of the Working: Assessing Skills, Habits, and Style questionnaire, that competency was not included in the analysis. The competencies measured included (a) life-long learning, (b) permanent problem solving, (c) systems thinking, (d) a sense of quality, (e) taking responsibility, (f) information processing, (g) persisting, (h) adapting to change, and (i) working in teams.

Question 2 (Q2):

Are there significant differences in workforce competencies between students enrolled in nursing clinical experiences at community colleges that reflect exemplary policies and procedures versus students at community colleges that do not reflect exemplary policies and procedures?

Nursing programs were considered exemplary if the program manger responded that they strongly agree or agree with all 17 statements. An independent samples $t$ test was performed to compare group means from student scores on the working instrument at college with exemplary programs with students at colleges with non-exemplary programs. Students needed to answer all questions associated with a competency. If the student chose not to answer all questions related to a specific competency on either the pre-clinical or post-clinical of the Working: Assessing Skills, Habits, and Style questionnaire, that competency not was included in the analysis. A $t$ test was used to examine significant differences between the nine workplace competencies. Question 3 (Q3):

Are there significant differences in workforce competencies for students by various demographic factors? These factors include previous work experience, age, academic achievement, total number of hours required at the work site to complete the clinical experience, and the number of credits the student will be awarded for the completion of the clinical 
experience. Selected institutional variables were also measured including institutional size and the size of an institutions associate degree of nursing program; that is the number of students enrolled in the institutions associate degree of nursing program.

Percentages were reported across all categories. An Analysis of Variance (ANOVA) was used to compare means for previous work experience, age, academic achievement, number of credits awarded for the completion of the clinical experience, number of hours required at the worksite to complete the clinical experience, location of the institution, size of the institution, and the size of an institutions associate degree of nursing program; that is the number of students enrolled in the institutions associate degree of nursing program. Students needed to answer all questions associated with a competency. If the student chose not to answer all questions related to a specific competency on either the pre-clinical or post-clinical of the Working: Assessing Skills, Habits, and Style questionnaire, that competency not was included in the analysis.

Table 4 contains a summary of the analyses that was used to address each variable.

Table 4

Analysis to be used by Research Variable

\begin{tabular}{llccc}
\hline \multicolumn{1}{c}{ Variable } & Mean & Percentage & $t$ test & ANOVA \\
\hline Pre-Clinical Experience Score & + & + & \\
Post-Clinical Experience Score & + & & + & \\
Exemplary/Non-Exemplary & + & & + & + \\
Previous Work Experience & & + & + \\
Age & & & + \\
Academic Achievement & + & & + \\
Number of Credits & + & + & + \\
Number Clinical Hours & + & + & + \\
Size of the Institution & + & + & + \\
Number of ADN Students & + & + & + \\
\hline
\end{tabular}




\section{Chapter Summary}

Community colleges play a significant role developing workforce competencies. One of the tools used to develop workforce competencies is the use of work-based learning experiences (e.g., clinical experiences). It is logical to assume that colleges which possessed exemplary policies and procedures in their work-based learning programs will result in students that participate in work-based learning experiences having a beneficial learning experience. Data and an analysis of response patterns will be reported in the next chapter. 


\section{Chapter Four}

Findings

\section{Introduction}

This chapter presents the findings of the study designed to compare the pre-clinical and post-clinical workplace competency scores of community college students enrolled in the first semester of an associate degree in nursing. The major results are reported according to three research questions. The purpose of the study was to determine if community college nursing students who participated in a work-based learning clinical experience developed basic workplace competencies necessary to work effectively in the workplace.

Eight Maryland community colleges agreed to participate in this study during the fall semester of 2004. Two of the community colleges were considered to be large (> 5,000 full-time equivalent (FTE) academic students), four were considered medium-sized community colleges (between 2,000 and 5,000 FTE academic students), and two small community colleges $(<2,000$ FTE academic students)(MHEC, 2005). Five community college nursing degree programs reflected exemplary policies and procedures of two-year work-based learning programs, three community colleges nursing degree program did not reflect exemplary policies and procedures of two-year work based learning programs as defined by Bragg and Hamm (1996).

\section{Participation}

Two hundred sixty four students participated in the study. Students were asked to complete demographic surveys and the Working: Assessing Skills, Habits, and Style questionnaire during each visit. The community colleges were visited by the researcher in late August and early September of 2004 before the beginning of student's clinical experience. The schools were again visited in late November and early December of 2004 at the end of the semester after the students had completed their clinical experience. 
The majority of the students, 55\% ( $n=146)$, were from schools that exhibited exemplary policies and procedures of two-year community college work-based learning programs as defined by Bragg and Hamm (1996). Forty-five percent $(n=118)$, where from schools that did not exhibit exemplary policies and procedures. Twenty-five percent of the students were between the ages 18 to 22 ( $n=67)$; 29\% were between the ages 23 to $30(n=77)$; age group 31 to 38 comprised $24 \%(n=62)$ of the students; age group 39 to 46 comprised $14 \%$ of the participants $(n=38)$; $6 \%$ were in the 47 to 54 age group $(n=15)$, and $1 \%$ were over the age of $55(n=3)$ (see Table 5). Twenty-three percent of the students $(n=60)$ that participated in the study were enrolled in community colleges with an annual enrollment of under 2,000 full-time equivalent (FTE) academic students, 45\% $(n=119)$ were enrolled in community colleges with an enrollment between 2,000 and 5,000 FTE students, and 32\% $(n=85)$ of the students attended schools with an annual FTE enrollment of more than 5,000 FTE.

Participants were coded based on the size of their institution's associate degree of nursing program (ADN); that is, the number of students enrolled in the institutions ADN program. Programs were segmented into three groups, small (fewer than 117 students), medium (between 117 and 159 students), and large (program with more 159 students) based on the student’s institutional ADN program size in relation to one-half degrees of the standard deviation of the standard mean size of the participating ADN programs $(M=138)$. Furthermore, $30.3 \%$ of the students $(n=80)$ where enrolled in a small programs, 32.6\% $(n=86)$ were enrolled in a medium sized programs, and 37.1\% $(n=98)$ were enrolled in large programs.

\section{Major Findings}

Research Question One.

This question examined the types of gains demonstrated by students participating in nursing clinical experiences. The competencies measured included 
Table 5

Student Characteristics and Demographic Data of Respondents

Number $\quad \%$

Age

$18-22$

67

26

$23-30$

77

29

$31-38$

62

24

$39-46$

38

15

$47-54$

15

6

55 or older

3

1

Years of Previous Full-Time Workforce Experience

$1-10$

163

64

11- 20

65

25

$21-30$

22

9

Over 31

6

2

Student Participation by Student Achievement (GPA)

$2.00-2.99$

35

13

3.00 - 3.99

191

73

4.00

35

13 
(a) life-long learning (WC1), (b) permanent problem solving (WC2), (c) systems thinking (WC3), (d) a sense of quality (WC4), (e) taking responsibility (WC5), (f) information processing (WC6), (g) persisting (WC7), (h) adapting to change (WC8), and (i) working in teams (WC9). According to student perceptions, eight of nine competencies decreased and three of the eight were significantly different. The only one that increased, WC1, life-long learning' was not statistically significant. A paired sample $t$ test was conduced to compare the mean scores of students from each of the nine key workplace competencies to determine if there are any significant differences. A significant difference decrease was found between the means of taking responsibility (WC5), persisting (WC7), and working in teams (WC9). A significant difference decrease was found between the means of WC5, taking responsibility, from the pre-clinical experience $(M=22.11, S D=3.546)$ to the post-clinical experience $(M=21.57, S D=3.311)$, $t(259)=2.447, p<.05$. It was further found the there was a significant difference decrease between the means of WC7, persisting, from the pre-clinical experience $(M=24.83, S D=3.763)$ to the post-clinical experience $(M=24.25, S D=3.644), t(258)=2.383, p<.05$. It was also found that there was a significant difference decrease between the means of WC9, working in teams, from the pre-clinical experience $(M=20.61, S D=3.765)$ to the post-clinical experience $(M=19.73, S D=4.081), t(257)=3.362, p<.05$ (see Table 6$).$

\section{Research Question Two}

Research question two sought to determine if there were significant differences in the workforce competencies scores between students enrolled in nursing clinical experiences at community colleges that reflect exemplary policies and procedures versus students at community colleges that do not reflect exemplary policies and procedures. There were no significant differences between the pre-clinical and post-clinical scores of students from schools that reflected exemplary policies and procedures and schools that did not reflect exemplary policies and procedures (see Table 7). 
Table 6

Differences on Working: Assessing Skills, Habits, and Style Questionnaire by Pre-clinical and Post-clinical Scores

\begin{tabular}{|c|c|c|c|c|c|}
\hline \multirow[t]{2}{*}{ Workplace Competency } & \multicolumn{2}{|c|}{ Pre-Clinical } & \multicolumn{2}{|c|}{ Post-Clinical } & \multirow[t]{2}{*}{$t$} \\
\hline & Mean & $S D$ & Mean & $S D$ & \\
\hline WC1 Life-long Learning ${ }^{\mathrm{b}}$ & 22.30 & 3.681 & 22.34 & 3.751 & -.181 \\
\hline WC2 Permanent Problem Solving ${ }^{\mathrm{d}}$ & 14.47 & 2.518 & 14.39 & 2.476 & .463 \\
\hline WC3 Systems Thinking ${ }^{\mathrm{d}}$ & 14.63 & 2.351 & 14.36 & 2.475 & 1.709 \\
\hline WC4 As a Sense of Quality ${ }^{\mathrm{e}}$ & 23.03 & 3.675 & 22.65 & 3.908 & 1.573 \\
\hline WC5 Taking Responsibility ${ }^{\mathrm{c}}$ & 22.11 & 3.546 & 21.57 & 3.311 & $2.447^{*}$ \\
\hline WC6 Information Processing ${ }^{\mathrm{b}}$ & 23.22 & 3.687 & 23.17 & 3.918 & .182 \\
\hline WC7 Persisting & 24.83 & 3.763 & 24.25 & 3.644 & $2.383^{*}$ \\
\hline WC8 Adapting to Change ${ }^{\mathrm{c}}$ & 18.70 & 4.089 & 18.50 & 4.431 & .807 \\
\hline WC9 Working in Teams ${ }^{\mathrm{a}}$ & 20.61 & 3.765 & 19.73 & 4.081 & $3.362 *$ \\
\hline
\end{tabular}


Table 7

Differences on Working: Assessing Skills, Habits, and Style Questionnaire Pre-clinical and Post-clinical Scores, Between Students Enrolled in Exemplary and Non-exemplary Nursing Programs

\begin{tabular}{|c|c|c|c|c|c|c|}
\hline & \multirow[t]{2}{*}{ Workplace Competency } & \multicolumn{2}{|c|}{ Exemplary } & \multicolumn{2}{|c|}{ Non-Exemplary } & \multirow[t]{2}{*}{$t$} \\
\hline & & Mean & $S D$ & Mean & $S D$ & \\
\hline \multirow{9}{*}{ Pre- Clinical } & WC1 Life-long Learning ${ }^{\mathrm{b}}$ & 22.10 & 3.862 & 22.57 & 3.433 & -1.020 \\
\hline & WC2 Permanent Problem Solving ${ }^{\mathrm{d}}$ & 14.54 & 2.420 & 14.38 & 2.642 & .528 \\
\hline & WC3 Systems Thinking ${ }^{\mathrm{d}}$ & 14.59 & 2.253 & 14.67 & 2.477 & -.270 \\
\hline & WC4 As a Sense of Quality ${ }^{\mathrm{e}}$ & 22.58 & 3.853 & 23.59 & 3.376 & -2.229 \\
\hline & WC5 Taking Responsibility ${ }^{c}$ & 22.03 & 3.365 & 22.20 & 3.772 & -.369 \\
\hline & WC6 Information Processing ${ }^{\mathrm{b}}$ & 23.29 & 3.691 & 23.13 & 3.696 & .349 \\
\hline & WC7 Persisting ${ }^{\mathrm{b}}$ & 24.71 & 3.953 & 24.97 & 3.519 & -.558 \\
\hline & WC8 Adapting to Change ${ }^{c}$ & 18.56 & 3.952 & 18.87 & 4.262 & -.612 \\
\hline & WC9 Working in Teams ${ }^{\mathrm{a}}$ & 20.56 & 3.886 & 20.67 & 3.628 & -.231 \\
\hline \multirow{9}{*}{ Post-Clinical } & WC1 Life-long Learning ${ }^{\mathrm{b}}$ & 22.36 & 3.601 & 22.32 & 3.953 & .094 \\
\hline & WC2 Permanent Problem Solving ${ }^{\mathrm{d}}$ & 14.44 & 2.538 & 14.33 & 2.407 & .337 \\
\hline & WC3 Systems Thinking ${ }^{\mathrm{d}}$ & 14.28 & 2.507 & 14.47 & 2.440 & -.642 \\
\hline & WC4 As a Sense of Quality ${ }^{\mathrm{e}}$ & 22.36 & 3.929 & 23.00 & 3.869 & -1.323 \\
\hline & WC5 Taking Responsibility ${ }^{\mathrm{c}}$ & 21.51 & 3.518 & 21.65 & 3.048 & -.321 \\
\hline & WC6 Information Processing & 23.41 & 4.092 & 22.88 & 3.685 & 1.085 \\
\hline & WC7 Persisting ${ }^{\mathrm{b}}$ & 24.15 & 3.781 & 24.38 & 3.475 & -.494 \\
\hline & WC8 Adapting to Change ${ }^{\mathrm{c}}$ & 18.48 & 4.145 & 18.53 & 4.775 & -.098 \\
\hline & WC9 Working in Teams ${ }^{\mathrm{a}}$ & 19.76 & 4.110 & 19.70 & 4.063 & .122 \\
\hline
\end{tabular}


A paired samples $t$ test was used to compare the workplace competency mean scores of students that attended schools that exhibited exemplary policies and procedures. The $t$ test did not reveal significant differences in the pre-clinical and post-clinical workplace competency mean scores of students that attended schools that exhibited exemplary policies and procedures. The $t$ test did reveal significant differences in the pre-clinical and post-clinical workplace competency mean scores of students that attended schools that did not exhibit exemplary policies and procedures. There was a significant difference decrease between the means of WC7, persisting, from the pre-clinical experience $(M=24.97, S D=3.518)$ to the post-clinical experience $(M=24.38$, $S D=3.475), t(114)=2.125, p<.05$. (see Table 8$)$.

\section{Research Question Three.}

Research question three sought to determine if there were significant differences in workforce competencies for students by various demographic factors. These factors include previous work experience, age, academic achievement, the total number of hours required to complete the clinical experience, and the number of credits the student will be awarded for the completion of the clinical experience. Selected institutional variables were also measured including institutional size and the size of an institutions associate degree of nursing program; that is the number of students enrolled in the institutions associate degree of nursing program. A one-way analysis of variance (ANOVA) was used to compare the students pre-clinical and postclinical mean scores based on the students previous work experience. No significant differences were found between the mean scores based on the difference between the student's previous work experiences (see Table 9).

An ANOVA was used to determine if there was a significant difference in the competency scores by age. To maximize statistical power, six age groups were collapsed into four groups thereby resulting in an increase in the total number of students in each group. Significant differences appeared in the pre-clinical experience scores for three competencies: life-long learning $(\mathrm{WC} 1)(\mathrm{F}(3,256)=5.84, \mathrm{p}<.05)$, a sense of quality (WC4) $(\mathrm{F}(3,259)=3.20, \mathrm{p}<.05)$, and adapting to change $(\mathrm{WC} 8)(\mathrm{F}(3,257)=3.41, \mathrm{p}<.05)$. 
Table 8

Differences on Working: Assessing Skills, Habits, and Style Questionnaire Pre-clinical and Post-clinical Scores, Within Exemplary and Non-exemplary Nursing Programs

\begin{tabular}{|c|c|c|c|c|c|c|}
\hline & \multirow[t]{2}{*}{ Workplace Competency } & \multicolumn{2}{|c|}{ Pre } & \multicolumn{2}{|c|}{ Post } & \multirow[t]{2}{*}{$t$} \\
\hline & & $M$ & $S D$ & $M$ & $S D$ & \\
\hline \multirow{9}{*}{ Exemplary } & WC1 Life-long Learning ${ }^{\mathrm{e}}$ & 22.10 & 3.862 & 22.36 & 3.601 & -0.799 \\
\hline & WC2 Permanent Problem Solving & 14.54 & 2.420 & 14.44 & 2.538 & 0.429 \\
\hline & WC3 Systems Thinking ${ }^{\mathrm{d}}$ & 14.59 & 2.253 & 14.28 & 2.507 & 1.472 \\
\hline & WC4 As a Sense of Quality ${ }^{\mathrm{d}}$ & 22.58 & 3.853 & 22.36 & 3.929 & 0.602 \\
\hline & WC5 Taking Responsibility & 22.03 & 3.365 & 21.51 & 3.518 & 1.651 \\
\hline & WC6 Information Processing ${ }^{\mathrm{c}}$ & 23.29 & 3.691 & 23.41 & 4.092 & -0.310 \\
\hline & WC7 Persisting ${ }^{\mathrm{d}}$ & 24.71 & 3.953 & 24.15 & 3.781 & 1.504 \\
\hline & WC8 Adapting to Change ${ }^{\mathrm{b}}$ & 18.56 & 3.952 & 18.48 & 4.145 & 0.240 \\
\hline & WC9 Working in Teams ${ }^{\mathrm{a}}$ & 20.56 & 3.886 & 19.76 & 4.110 & 1.958 \\
\hline \multirow{9}{*}{ Non-Exemplary } & WC1 Life-long Learning ${ }^{f}$ & 22.57 & 3.433 & 22.32 & 3.953 & 0.778 \\
\hline & WC2 Permanent Problem Solving & 14.38 & 2.642 & 14.33 & 2.407 & 0.197 \\
\hline & WC3 Systems Thinkingi & 14.67 & 2.477 & 14.47 & 2.440 & 0.895 \\
\hline & WC4 As a Sense of Quality ${ }^{j}$ & 23.59 & 3.376 & 23.00 & 3.869 & 1.914 \\
\hline & WC5 Taking Responsibility ${ }^{\mathrm{i}}$ & 22.20 & 3.772 & 21.65 & 3.048 & 1.867 \\
\hline & WC6 Information Processing & 23.13 & 3.696 & 22.88 & 3.685 & 0.793 \\
\hline & WC7 Persisting ${ }^{g}$ & 24.97 & 3.518 & 24.38 & 3.475 & $2.125^{*}$ \\
\hline & WC8 Adapting to Change ${ }^{\mathrm{j}}$ & 18.87 & 4.262 & 18.53 & 4.775 & 0.982 \\
\hline & WC9 Working in Teams ${ }^{\mathrm{i}}$ & 20.67 & 3.628 & 19.70 & 4.063 & $3.282 *$ \\
\hline
\end{tabular}

Note. Pre $=$ pre-clinical; Post $=$ post-clinical

${ }^{\mathrm{a}} n=142{ }^{\mathrm{b}} n=143 .{ }^{\mathrm{c}} n=144 .{ }^{\mathrm{d}} n=145 .{ }^{\mathrm{e}} \mathrm{n}=146$.

${ }^{\mathrm{f}} n=113{ }^{\mathrm{g}} n=114 .{ }^{\mathrm{h}} n=115 .{ }^{\mathrm{i}} n=116 .{ }^{\mathrm{j}} \mathrm{n}=117$.

$* p<.05$ 
Table 9

Differences on Working: Assessing Skills, Habits, and Style Questionnaire Pre-clinical and Post-clinical Scores, Between Groups with Different Years of Previous Work Experience

\begin{tabular}{|c|c|c|c|c|c|c|c|c|c|c|}
\hline & \multirow[t]{2}{*}{ Workplace Competency } & \multicolumn{2}{|c|}{$\begin{array}{c}\text { Group } 1 \\
(1-10)\end{array}$} & \multicolumn{2}{|c|}{$\begin{array}{c}\text { Group } 2 \\
(11-20)\end{array}$} & \multicolumn{2}{|c|}{$\begin{array}{l}\text { Group } 3 \\
(21-30)\end{array}$} & \multicolumn{2}{|c|}{$\begin{array}{c}\text { Group } 4 \\
\text { (31 or Over) }\end{array}$} & \multirow[t]{2}{*}{$F$} \\
\hline & & $M$ & $S D$ & $M$ & $S D$ & $M$ & $S D$ & $M$ & $S D$ & \\
\hline & WC1 Life-long Learning ${ }^{a}$ & 22.08 & 3.512 & 22.77 & 3.836 & 22.60 & 4.871 & 23.67 & 1.506 & 0.859 \\
\hline & WC2 Permanent Problem Solving ${ }^{\mathrm{C}}$ & 14.28 & 2.535 & 14.72 & 2.548 & 14.52 & 2.400 & 15.67 & 2.658 & 0.941 \\
\hline & WC3 Systems Thinking ${ }^{c}$ & 14.51 & 2.370 & 14.95 & 2.196 & 14.77 & 2.759 & 13.83 & 2.927 & 0.770 \\
\hline & WC4 As a Sense of Quality ${ }^{\mathrm{d}}$ & 22. 86 & 3.544 & 23.65 & 3.879 & 23.05 & 4.177 & 23.50 & 1.761 & 0.743 \\
\hline \multirow[t]{9}{*}{ Pre } & WC5 Taking Responsibility ${ }^{\mathrm{b}}$ & 21.94 & 3.580 & 22.42 & 3.230 & 22.75 & 4.387 & 21.33 & 3.445 & 0.586 \\
\hline & WC6 Information Processing ${ }^{\mathrm{a}}$ & 22.86 & 3.629 & 23.97 & 3.328 & 23.00 & 4.572 & 23.17 & 3.917 & 1.431 \\
\hline & WC7 Persisting ${ }^{\mathrm{a}}$ & 24.63 & 3.643 & 25.41 & 3.295 & 24.19 & 5.896 & 25.83 & 2.483 & 0.995 \\
\hline & WC8 Adapting to Change ${ }^{\mathrm{b}}$ & 18.26 & 4.109 & 19.90 & 3.851 & 18.76 & 4.668 & 18.80 & 3.962 & 2.436 \\
\hline & WC9 Working in Teams ${ }^{\mathrm{a}}$ & 20.51 & 3.680 & 20.59 & 4.226 & 20.57 & 3.140 & 21.17 & 3.061 & 0.062 \\
\hline & WC1 Life-long Learning ${ }^{\mathrm{a}}$ & 22.19 & 3.690 & 22.75 & 3.636 & 22.65 & 4.171 & 22.17 & 3.971 & 0.394 \\
\hline & WC2 Permanent Problem Solving ${ }^{\mathrm{c}}$ & 14.36 & 2.250 & 14.48 & 2.938 & 14.38 & 2.617 & 15.00 & 2.828 & 0.156 \\
\hline & WC3 Systems Thinking ${ }^{\mathrm{c}}$ & 14.33 & 2.343 & 14.30 & 2.825 & 13.77 & 2.329 & 14.83 & 1.941 & 0.439 \\
\hline & WC4 As a Sense of Quality ${ }^{\mathrm{d}}$ & 22.33 & 3.693 & 23.37 & 4.418 & 22.90 & 3.491 & 23.67 & 5.241 & 1.262 \\
\hline \multirow[t]{5}{*}{ Post } & WC5 Taking Responsibility ${ }^{\mathrm{b}}$ & 21.56 & 3.190 & 21.48 & 3.771 & 22.50 & 2.646 & 22.17 & 1.722 & 0.591 \\
\hline & WC6 Information Processing ${ }^{\mathrm{a}}$ & 22.97 & 3.474 & 23.66 & 4.848 & 22.38 & 4.189 & 23.50 & 3.017 & 0.745 \\
\hline & WC7 Persisting ${ }^{\mathrm{a}}$ & 24.17 & 3.241 & 24.38 & 4.316 & 24.48 & 4.070 & 23.83 & 4.792 & 0.103 \\
\hline & WC8 Adapting to Change ${ }^{\mathrm{b}}$ & 18.26 & 4.520 & 19.44 & 4.011 & 18.14 & 4.871 & 14.80 & 2.683 & 2.343 \\
\hline & WC9 Working in Teams ${ }^{\mathrm{a}}$ & 19.66 & 4.103 & 19.51 & 4.119 & 19.86 & 3.336 & 19.67 & 3.933 & 0.045 \\
\hline
\end{tabular}

Note. Pre $=$ pre-clinical; Post $=$ post-clinical

${ }^{\mathrm{a}} n=250 .{ }^{\mathrm{b}} n=251 .{ }^{\mathrm{c}} n=252 .{ }^{\mathrm{d}} n=253$.

$* p<.05$ 
Significant differences also appeared in the post-clinical experience scores for the same three competencies, life-long learning $(\mathrm{WC1})(F(3,256)=4.24, p<.05)$, a sense of quality (WC4) $(F(3,259)=3.36, p<.05)$, and adapting to change $(\mathrm{WC})(F(3,257)=3.26, p<.05)$ (see Table 10). Tukey’s HSD was used to determine the nature of the differences between the different age groups. This analysis revealed that students age $18-22$ scored $(M=20.73, S D=3.51)$ lower in their pre-clinical scores for competency WC1, life-long learning, than students age 23-30 $(M=$ 22.47, $S D=3.58)$, students age 31-38 $(M=22.93, S D=3.75)$, and students 39 years of age or older $(M=23.09, S D=3.94)$. It was also revealed that students $18-22$ years of age scored $(M=$ 21.89, $S D=3.54$ ) lower in their pre-clinical scores for competency WC4, a sense of quality, than students 39 years of age or older $(M=23.89, S D=3.24)$. It was further revealed that students 18 22 scored $(M=17.58, S D=4.11)$ lower in their pre-clinical scores for competency WC8, adapting to change, than students 39 years of age or older $(M=19.65, S D=4.31)$. Tukey’s HSD also revealed that students age $18-22$ scored $(M=20.92, S D=3.69)$ lower in their post-clinical scores for competency WC1, life-long learning, than students age 23-30 $(M=22.72, S D=3.60)$, students age $31-38(M=22.87, S D=3.51)$, and students 39 years of age or older $(M=22.81, S D$ = 3.95). It was also revealed that students $18-22$ scored $(M=21.58, S D=3.69)$ lower in their post-clinical scores for competency WC4, a sense of quality, than students 39 years of age or older $(M=23.60, S D=3.81)$. It was further revealed that students $18-22$ scored $(M=17.27, S D$ $=4.52$ ) lower in their post-clinical scores for competency WC8, adapting to change, than students 31 to 38 years of age $(M=19.59, S D=4.53)$.

A one-way analysis of variance (ANOVA) was used to compare students’ pre-clinical and post-clinical mean scores based on the student's different levels of academic achievement. A significant difference appeared in the post-clinical experience score for one competency, a sense of quality $($ WC4 $)(F(2,258)=4.84, p<.05)$ (see Table 11$)$. Tukey’s HSD was used to determine 
Table 10

Differences on Working: Assessing Skills, Habits, and Style Questionnaire Pre-clinical and Post-clinical Scores, Between Groups with Different Years of Age

\begin{tabular}{|c|c|c|c|c|c|c|c|c|c|c|}
\hline & \multirow[t]{2}{*}{ Workplace Competency } & \multicolumn{2}{|c|}{$\begin{array}{l}\text { Group } 1 \\
(18-22)\end{array}$} & \multicolumn{2}{|c|}{$\begin{array}{c}\text { Group } 2 \\
(23-30)\end{array}$} & \multicolumn{2}{|c|}{$\begin{array}{l}\text { Group } 3 \\
(31-38)\end{array}$} & \multicolumn{2}{|c|}{$\begin{array}{c}\text { Group } 4 \\
\text { (39 or Over) }\end{array}$} & \multirow[t]{2}{*}{$F$} \\
\hline & & $M$ & $S D$ & $M$ & $S D$ & $M$ & $S D$ & $M$ & $S D$ & \\
\hline \multirow{9}{*}{ Pre } & WC1 Life-long Learning ${ }^{\mathrm{b}}$ & 20.73 & 3.512 & 22.47 & 3.576 & 22.93 & 3.750 & 23.09 & 3.939 & $5.844 *$ \\
\hline & WC2 Permanent Problem Solving ${ }^{\mathrm{d}}$ & 14.36 & 2.535 & 14.49 & 2.447 & 14.48 & 2.487 & 14.49 & 2.673 & .041 \\
\hline & WC3 Systems Thinking ${ }^{\mathrm{d}}$ & 14.31 & 2.370 & 14.64 & 2.406 & 14.75 & 2.482 & 14.86 & 2.467 & .620 \\
\hline & WC4 As a Sense of Quality ${ }^{\mathrm{e}}$ & 21.89 & 3.544 & 23.27 & 3.669 & 23.16 & 4.399 & 23.89 & 3.241 & $3.320 *$ \\
\hline & WC5 Taking Responsibility ${ }^{\mathrm{c}}$ & 21.73 & 3.643 & 22.01 & 3.622 & 22.51 & 3.515 & 22.30 & 3.500 & .578 \\
\hline & WC6 Information Processing ${ }^{\mathrm{b}}$ & 22.48 & 3.629 & 23.09 & 3.621 & 24.23 & 3.524 & 23.11 & 3.941 & 2.465 \\
\hline & WC7 Persisting ${ }^{\mathrm{b}}$ & 24.15 & 3.643 & 24.91 & 3.614 & 24.71 & 4.660 & 25.57 & 3.300 & 1.454 \\
\hline & WC8 Adapting to Change ${ }^{c}$ & 17.58 & 4.109 & 18.45 & 3.965 & 19.41 & 4.039 & 19.65 & 4.314 & $3.410 *$ \\
\hline & WC9 Working in Teams ${ }^{\mathrm{a}}$ & 21.00 & 3.680 & 20.08 & 3.376 & 20.10 & 4.277 & 21.22 & 3.396 & 1.605 \\
\hline \multirow{9}{*}{ Post } & WC1 Life-long Learning ${ }^{\mathrm{b}}$ & 20.92 & 3.690 & 22.72 & 3.595 & 22.87 & 3.514 & 22.81 & 3.953 & $4.241 *$ \\
\hline & WC2 Permanent Problem Solving ${ }^{\mathrm{d}}$ & 14.13 & 2.250 & 14.41 & 2.456 & 14.38 & 2.770 & 14.60 & 2.506 & .364 \\
\hline & WC3 Systems Thinking ${ }^{\mathrm{d}}$ & 14.34 & 2.343 & 14.43 & 2.536 & 14.31 & 2.493 & 14.29 & 2.599 & .044 \\
\hline & WC4 As a Sense of Quality ${ }^{\mathrm{e}}$ & 21.58 & 3.693 & 22.36 & 3.842 & 23.19 & 4.168 & 23.60 & 3.813 & $3.357 *$ \\
\hline & WC5 Taking Responsibility ${ }^{\mathrm{c}}$ & 21.38 & 3.190 & 21.69 & 3.686 & 21.61 & 3.593 & 21.57 & 3.351 & .107 \\
\hline & WC6 Information Processing ${ }^{\mathrm{b}}$ & 22.32 & 3.474 & 23.57 & 3.454 & 23.68 & 4.398 & 22.93 & 4.455 & 1.737 \\
\hline & WC7 Persisting ${ }^{\mathrm{b}}$ & 23.61 & 3.241 & 24.31 & 3.613 & 24.48 & 4.064 & 24.57 & 3.970 & .914 \\
\hline & WC8 Adapting to Change ${ }^{\mathrm{c}}$ & 17.27 & 4.520 & 18.34 & 4.226 & 19.59 & 4.533 & 19.02 & 4.196 & $3.260 *$ \\
\hline & WC9 Working in Teams ${ }^{\mathrm{a}}$ & 19.74 & 4.103 & 20.12 & 4.439 & 19.10 & 4.206 & 19.85 & 3.389 & .724 \\
\hline
\end{tabular}

Note. Pre $=$ pre-clinical; Post $=$ post-clinical

${ }^{\mathrm{a}} n=255 .{ }^{\mathrm{b}} n=256 .{ }^{\mathrm{c}} n=257 .{ }^{\mathrm{d}} n=258 .{ }^{\mathrm{e}} \mathrm{n}=259$.

${ }^{*} p<.05$ 
Table 11

Differences on Working: Assessing Skills, Habits, and Style Questionnaire Pre-clinical and Post-clinical Scores, Between Groups with Different Levels of Academic Achievement

\begin{tabular}{|c|c|c|c|c|c|c|c|c|}
\hline & \multirow[t]{2}{*}{ Workplace Competency } & \multicolumn{2}{|c|}{$\begin{array}{c}\text { Group } 1 \\
(2.00-2.99)\end{array}$} & \multicolumn{2}{|c|}{$\begin{array}{c}\text { Group } 2 \\
(3.00-3.99)\end{array}$} & \multicolumn{2}{|c|}{$\begin{array}{c}\text { Group } 3 \\
(4.00)\end{array}$} & \multirow[t]{2}{*}{$F$} \\
\hline & & $M$ & $S D$ & $M$ & $S D$ & $M$ & $S D$ & \\
\hline \multirow{9}{*}{ Pre } & WC1 Life-long Learning ${ }^{c}$ & 22.62 & 4.228 & 22.04 & 3.655 & 23.34 & 3.217 & 1.992 \\
\hline & WC2 Permanent Problem Solving ${ }^{\mathrm{d}}$ & 14.94 & 2.376 & 14.42 & 2.520 & 14.23 & 2.658 & .813 \\
\hline & WC3 Systems Thinking ${ }^{\mathrm{d}}$ & 15.37 & 2.658 & 14.48 & 2.263 & 14.68 & 2.458 & 2.134 \\
\hline & WC4 As a Sense of Quality ${ }^{\mathrm{e}}$ & 22.54 & 4.032 & 22.93 & 3.684 & 23.97 & 3.321 & 1.513 \\
\hline & WC5 Taking Responsibility ${ }^{\mathrm{c}}$ & 22.14 & 3.050 & 22.04 & 3.687 & 22.34 & 3.412 & .112 \\
\hline & WC6 Information Processing ${ }^{\mathrm{b}}$ & 23.97 & 3.563 & 23.03 & 3.711 & 23.62 & 3.758 & 1.153 \\
\hline & WC7 Persisting & 24.80 & 4.296 & 24.67 & 3.694 & 25.68 & 3.641 & 1.027 \\
\hline & WC8 Adapting to Change ${ }^{c}$ & 19.20 & 4.418 & 18.51 & 4.019 & 19.31 & 4.220 & .856 \\
\hline & WC9 Working in Teams ${ }^{\mathrm{a}}$ & 21.43 & 3.146 & 20.51 & 3.778 & 20.37 & 4.373 & .947 \\
\hline \multirow{9}{*}{ Post } & WC1 Life-long Learning ${ }^{\mathrm{c}}$ & 21.47 & 4.308 & 22.25 & 3.738 & 23.57 & 3.042 & 2.879 \\
\hline & WC2 Permanent Problem Solving ${ }^{\mathrm{d}}$ & 14.63 & 2.045 & 14.32 & 2.583 & 14.49 & 2.418 & .250 \\
\hline & WC3 Systems Thinking ${ }^{\mathrm{d}}$ & 14.20 & 2.324 & 14.29 & 2.587 & 14.88 & 2.012 & .906 \\
\hline & WC4 As a Sense of Quality ${ }^{\mathrm{e}}$ & 21.43 & 3.905 & 22.58 & 3.784 & 24.26 & 4.154 & $4.841 *$ \\
\hline & WC5 Taking Responsibility ${ }^{\mathrm{c}}$ & 21.23 & 3.797 & 21.46 & 3.232 & 22.46 & 3.147 & 1.554 \\
\hline & WC6 Information Processing ${ }^{\mathrm{b}}$ & 23.97 & 3.424 & 22.92 & 4.060 & 23.74 & 3.562 & 1.444 \\
\hline & WC7 Persisting & 24.09 & 3.501 & 24.09 & 3.671 & 25.24 & 3.701 & 1.461 \\
\hline & WC8 Adapting to Change ${ }^{c}$ & 18.23 & 4.499 & 18.44 & 4.449 & 19.14 & 4.525 & .445 \\
\hline & WC9 Working in Teams ${ }^{\mathrm{a}}$ & 20.23 & 3.388 & 19.86 & 4.230 & 18.57 & 3.752 & 1.780 \\
\hline
\end{tabular}

Note. Pre = pre-clinical; Post $=$ post-clinical

${ }^{\mathrm{a}} n=254 .{ }^{\mathrm{b}} n=255 .{ }^{\mathrm{c}} n=256 .{ }^{\mathrm{d}} n=257 .{ }^{\mathrm{e}} \mathrm{n}=258$.

${ }^{*} p<.05$ 
the nature of the differences between the students with different academic achievement levels. The analysis revealed that students with a 4.00 grade point average (GPA) scored significantly $(M=24.26, S D=4.15)$ higher in their post-clinical score for competency WC4, a sense of quality, than students with GPAs between 2.00-2.99 $(M=21.43, S D=3.91)$, and students with a GPA between 3.00-3.99 $(M=22.58, S D=3.78)$.

The researcher used a one-way analysis of variance (ANOVA) to compare the students' pre-clinical and post-clinical mean scores based on the number of credits the student was awarded for the completion of the clinical experience. The ANOVA revealed a significant difference in the pre-clinical score for one competency, systems thinking $(\mathrm{WC})(F(2,260)=$ $5.92, p, .05)$ and the post-clinical score for competency WC6, information processing $(F(2,258)$ $=4.34, p<.05$ ) (see Table 12). The Tukey HSD post-hoc test revealed that students that were awarded between 4 to 6 credits $(M=15.95, S D=2.12)$ had a higher competency score than students that were awarded 7 or more credits $(M=14.30, S D=2.41)$ upon completion of the clinical experience for the pre-clinical systems thinking (WC3) competency. The Tukey HSD also revealed that students that were awarded between 4 to 6 credits scored $(M=25.68, S D=$ 2.98) significantly higher for the post-clinical competency score WC6, information processing, than did students that were awarded between $1-3$ credits $(M=22.89, S D=3.88)$ and students that were awarded over 7 credits $(M=23.01, S D=3.95)$.

A one-way analysis of variance (ANOVA) was used to compare the students’ pre-clinical and post-clinical mean scores based on the size of the institution that the student attended. No significant differences were found between the mean scores based on the size of the student's institution (see Table 13).

A statistical analysis based on the total number of hours required to complete the clinical experience could not be performed due to the homogenous nature of the sample. All students 
Table 12

Differences on Working: Assessing Skills, Habits, and Style Questionnaire Pre-clinical and Post-clinical Scores, Between Groups with Different Number of Credits Awarded for the Completion of the Clinical Experience

\begin{tabular}{|c|c|c|c|c|c|c|c|c|}
\hline & \multirow[t]{2}{*}{ Workplace Competency } & \multicolumn{2}{|c|}{$\begin{array}{l}\text { Group } 1 \\
(1-3)\end{array}$} & \multicolumn{2}{|c|}{$\begin{array}{c}\text { Group } 2 \\
(4-6)\end{array}$} & \multicolumn{2}{|c|}{$\begin{array}{c}\text { Group } 3 \\
\text { (7 or Higher) }\end{array}$} & \multirow[t]{2}{*}{$F$} \\
\hline & & $M$ & $S D$ & $M$ & $S D$ & $M$ & $S D$ & \\
\hline \multirow{9}{*}{ Pre } & WC1 Life-long Learning ${ }^{\mathrm{b}}$ & 22.51 & 3.074 & 22.79 & 3.853 & 22.16 & 3.910 & .410 \\
\hline & WC2 Permanent Problem Solving ${ }^{\mathrm{d}}$ & 14.72 & 2.664 & 14.32 & 2.583 & 14.37 & 2.451 & .531 \\
\hline & WC3 Systems Thinking ${ }^{\mathrm{d}}$ & 15.03 & 2.099 & 15.95 & 2.121 & 14.30 & 2.414 & $5.918 *$ \\
\hline & WC4 As a Sense of Quality & 23.68 & 3.350 & 22.58 & 3.437 & 22.79 & 3.821 & 1.678 \\
\hline & WC5 Taking Responsibility ${ }^{\mathrm{c}}$ & 22.27 & 3.532 & 22.16 & 3.436 & 22.03 & 3.583 & .119 \\
\hline & WC6 Information Processing & 23.25 & 3.534 & 24.74 & 2.884 & 23.03 & 3.812 & 1.842 \\
\hline & WC7 Persisting ${ }^{\mathrm{b}}$ & 24.77 & 3.593 & 25.79 & 3.084 & 24.74 & 3.910 & .672 \\
\hline & WC8 Adapting to Change ${ }^{\mathrm{c}}$ & 18.72 & 4.325 & 18.95 & 4.327 & 18.66 & 3.973 & .043 \\
\hline & WC9 Working in Teams ${ }^{\mathrm{a}}$ & 20.85 & 3.313 & 18.67 & 3.630 & 20.72 & 3.926 & 2.650 \\
\hline \multirow{9}{*}{ Post } & WC1 Life-long Learning ${ }^{\mathrm{b}}$ & 22.34 & 3.408 & 23.58 & 3.220 & 22.20 & 3.939 & 1.148 \\
\hline & WC2 Permanent Problem Solving ${ }^{\mathrm{d}}$ & 14.33 & 2.549 & 14.68 & 1.797 & 14.38 & 2.519 & .153 \\
\hline & WC3 Systems Thinking ${ }^{\mathrm{d}}$ & 14.56 & 2.268 & 15.47 & 2.366 & 14.15 & 2.547 & 2.810 \\
\hline & WC4 As a Sense of Quality & 22.65 & 3.920 & 23.47 & 2.653 & 22.55 & 4.027 & .478 \\
\hline & WC5 Taking Responsibility ${ }^{\mathrm{c}}$ & 21.64 & 3.014 & 22.42 & 3.322 & 21.45 & 3.437 & .752 \\
\hline & WC6 Information Processing ${ }^{\mathrm{b}}$ & 22.89 & 3.875 & 25.68 & 2.982 & 23.01 & 3.951 & $4.342 *$ \\
\hline & WC7 Persisting ${ }^{\mathrm{b}}$ & 23.97 & 3.590 & 25.74 & 2.845 & 24.21 & 3.728 & 1.821 \\
\hline & WC8 Adapting to Change ${ }^{c}$ & 18.49 & 4.678 & 19.32 & 4.308 & 18.41 & 4.345 & .353 \\
\hline & WC9 Working in Teams ${ }^{\mathrm{a}}$ & 19.68 & 3.924 & 19.33 & 2.870 & 19.80 & 4.273 & .116 \\
\hline
\end{tabular}

Note. Pre = pre-clinical; Post $=$ post-clinical

${ }^{\mathrm{a}} n=257 .{ }^{\mathrm{b}} n=258 .{ }^{\mathrm{c}} n=259 .{ }^{\mathrm{d}} n=260 .{ }^{\mathrm{e}} \mathrm{n}=261$.

${ }^{*} p<.05$ 
Table 13

Differences on Working: Assessing Skills, Habits, and Style Questionnaire Pre-clinical and Post-clinical Scores Between Groups by the Size of the Student's Institution

\begin{tabular}{|c|c|c|c|c|c|c|c|c|}
\hline & \multirow[t]{2}{*}{ Workplace Competency } & \multicolumn{2}{|c|}{$\begin{array}{l}\text { Group } 1 \\
(<2,000)\end{array}$} & \multicolumn{2}{|c|}{$\begin{array}{c}\text { Group } 2 \\
(2,000-5,000)\end{array}$} & \multicolumn{2}{|c|}{$\begin{array}{l}\text { Group } 3 \\
(>5,000)\end{array}$} & \multirow[t]{2}{*}{$F$} \\
\hline & & $M$ & $S D$ & $M$ & $S D$ & $M$ & $S D$ & \\
\hline \multirow{9}{*}{ Pre } & WC1 Life-long Learning ${ }^{\mathrm{b}}$ & 22.57 & 3.728 & 22.40 & 3.323 & 21.99 & 4.113 & .498 \\
\hline & WC2 Permanent Problem Solving ${ }^{\mathrm{d}}$ & 14.13 & 2.466 & 14.60 & 2.485 & 14.52 & 2.610 & .711 \\
\hline & WC3 Systems Thinking ${ }^{\mathrm{d}}$ & 14.32 & 2.707 & 14.96 & 2.077 & 14.38 & 2.414 & 2.142 \\
\hline & WC4 As a Sense of Quality ${ }^{\mathrm{e}}$ & 23.17 & 3.200 & 23.29 & 3.412 & 22.57 & 4.297 & .986 \\
\hline & WC5 Taking Responsibility & 21.48 & 3.947 & 22.32 & 3.386 & 22.26 & 3.451 & 1.219 \\
\hline & WC6 Information Processing ${ }^{\mathrm{b}}$ & 23.14 & 3.692 & 23.39 & 3.426 & 23.04 & 4.049 & .247 \\
\hline & WC7 Persisting ${ }^{\mathrm{b}}$ & 24.86 & 3.686 & 25.14 & 3.251 & 24.36 & 4.425 & 1.077 \\
\hline & WC8 Adapting to Change ${ }^{\mathrm{c}}$ & 18.53 & 3.798 & 18.64 & 4.485 & 18.91 & 3.709 & .179 \\
\hline & WC9 Working in Teams ${ }^{\mathrm{a}}$ & 20.53 & 4.066 & 20.48 & 3.696 & 20.85 & 3.678 & .240 \\
\hline \multirow{9}{*}{ Post } & WC1 Life-long Learning ${ }^{\mathrm{b}}$ & 22.40 & 4.263 & 22.32 & 3.496 & 22.34 & 3.762 & .008 \\
\hline & WC2 Permanent Problem Solving ${ }^{\mathrm{d}}$ & 14.27 & 2.007 & 14.26 & 2.395 & 14.66 & 2.872 & .732 \\
\hline & WC3 Systems Thinking ${ }^{\mathrm{d}}$ & 14.29 & 2.400 & 14.55 & 2.315 & 14.15 & 2.740 & .663 \\
\hline & WC4 As a Sense of Quality ${ }^{\mathrm{e}}$ & 23.20 & 4.003 & 22.51 & 3.663 & 22.44 & 4.175 & .791 \\
\hline & WC5 Taking Responsibility ${ }^{\mathrm{c}}$ & 21.33 & 2.995 & 21.77 & 3.180 & 21.48 & 3.699 & .381 \\
\hline & WC6 Information Processing ${ }^{\mathrm{b}}$ & 23.00 & 3.564 & 23.21 & 3.798 & 23.24 & 4.337 & .074 \\
\hline & WC7 Persisting ${ }^{\mathrm{b}}$ & 24.54 & 3.485 & 24.43 & 3.301 & 23.80 & 4.173 & .980 \\
\hline & WC8 Adapting to Change ${ }^{\mathrm{c}}$ & 18.19 & 4.988 & 18.66 & 4.373 & 18.49 & 4.122 & .228 \\
\hline & WC9 Working in Teams ${ }^{\mathrm{a}}$ & 19.16 & 4.637 & 19.70 & 3.653 & 20.18 & 4.229 & 1.087 \\
\hline
\end{tabular}

\footnotetext{
Note. Pre = pre-clinical; Post $=$ post-clinical

${ }^{\mathrm{a}} n=257 .{ }^{\mathrm{b}} n=258 .{ }^{\mathrm{c}} n=259 .{ }^{\mathrm{d}} n=260 .{ }^{\mathrm{e}} \mathrm{n}=261$.

$* p<.05$
} 
enrolled at participating community colleges indicated that they were required to complete over 31 hours of work-based learning experiences at the work site.

The researcher next sought to determine if there were significant differences in the preclinical and post-clinical scores by the number of nursing students enrolled in the student's nursing degree program. A one-way analysis of variance (ANOVA) was used to compare the students’ pre-clinical and post-clinical mean scores. There was no significant difference found in the student's pre-clinical scores or post-clinical scores based on the number of nursing students enrolled in the student’s nursing degree program (see Table 14).

\section{Chapter Summary}

Students enrolled in a nursing clinical experience did not demonstrate gains in workplace competencies. To the contrary, students demonstrated a significant decrease in three workplace competencies: taking responsibility (WC5), persisting (WC7), and working in teams (WC9) (see Table 6). Data from Research Question Two revealed that were no significant differences between the pre-clinical and post-clinical scores of students' from schools that reflected exemplary policies and procedures and schools that did not reflect exemplary policies and procedures (see Table 7). A within samples test revealed that there were no significant differences in the pre-clinical and post-clinical competency scores of students from schools that reflected exemplary policies and procedures. However, students from schools that did not reflect exemplary policies and procedures did show significant decreases in their mean scores for competency WC7, persisting and competency WC9, working in teams (see Table 8). There were no significant differences in the students' competency scores based on each student's years of previous work experience (see Table 9). Significant differences were seen in the competency scores of students grouped by age. Significant differences were seen in three competencies: lifelong learning (WC1) a sense of quality (WC4), and adapting to change (WC8) (see Table 10). A 
Table 14

Differences on Working: Assessing Skills, Habits, and Style Questionnaire Pre-clinical and Post-clinical Scores by the Number of Nursing Students Enrolled in the Student's Nursing Degree Program

\begin{tabular}{|c|c|c|c|c|c|c|c|c|}
\hline & \multirow[t]{2}{*}{ Workplace Competency } & \multicolumn{2}{|c|}{$\begin{array}{l}\text { Group } 1 \\
(<117) \\
\end{array}$} & \multicolumn{2}{|c|}{$\begin{array}{c}\text { Group } 2 \\
(121-159) \\
\end{array}$} & \multicolumn{2}{|c|}{$\begin{array}{l}\text { Group } 3 \\
(>159)\end{array}$} & \multirow[t]{2}{*}{$F$} \\
\hline & & $\mathrm{M}$ & $\mathrm{SD}$ & $\mathrm{M}$ & $\mathrm{SD}$ & $\mathrm{M}$ & SD & \\
\hline \multirow{9}{*}{ Pre } & WC1 Life-long Learning ${ }^{\mathrm{b}}$ & 22.22 & 3.230 & 22.28 & 3.782 & 22.39 & 3.96 & 0.046 \\
\hline & WC2 Permanent Problem Solving ${ }^{\mathrm{d}}$ & 14.71 & 2.538 & 14.30 & 2.260 & 14.42 & 2.72 & 0.565 \\
\hline & WC3 Systems Thinking ${ }^{\mathrm{d}}$ & 14.70 & 2.028 & 14.64 & 2.280 & 14.56 & 2.66 & 0.071 \\
\hline & WC4 As a Sense of Quality ${ }^{\mathrm{e}}$ & 23.18 & 3.418 & 22.93 & 3.919 & 23.00 & 3.69 & 0.098 \\
\hline & WC5 Taking Responsibility ${ }^{\mathrm{c}}$ & 22.13 & 3.415 & 22.37 & 3.461 & 21.86 & 3.73 & 0.483 \\
\hline & WC6 Information Processing ${ }^{\mathrm{b}}$ & 23.28 & 3.545 & 22.83 & 3.495 & 23.53 & 3.96 & 0.830 \\
\hline & WC7 Persisting ${ }^{\mathrm{b}}$ & 24.95 & 3.404 & 24.62 & 4.059 & 24.91 & 3.80 & 0.185 \\
\hline & WC8 Adapting to Change ${ }^{c}$ & 18.49 & 4.360 & 18.86 & 4.223 & 18.74 & 3.76 & 0.173 \\
\hline & WC9 Working in Teams ${ }^{\mathrm{a}}$ & 20.94 & 3.774 & 20.06 & 3.617 & 20.84 & 3.87 & 1.387 \\
\hline \multirow{9}{*}{ Post } & WC1 Life-long Learning ${ }^{\mathrm{b}}$ & 21.78 & 3.548 & 22.64 & 3.320 & 22.54 & 4.23 & 1.267 \\
\hline & WC2 Permanent Problem Solving ${ }^{\mathrm{d}}$ & 13.97 & 2.253 & 14.50 & 2.505 & 14.64 & 2.60 & 1.676 \\
\hline & WC3 Systems Thinking ${ }^{\mathrm{d}}$ & 14.18 & 2.188 & 14.59 & 2.388 & 14.31 & 2.77 & 0.612 \\
\hline & WC4 As a Sense of Quality ${ }^{\mathrm{e}}$ & 22.01 & 3.838 & 22.80 & 3.687 & 23.02 & 4.13 & 1.559 \\
\hline & WC5 Taking Responsibility & 21.26 & 3.296 & 21.98 & 3.243 & 21.46 & 3.38 & 1.030 \\
\hline & WC6 Information Processing ${ }^{\mathrm{b}}$ & 22.63 & 3.707 & 23.41 & 3.743 & 23.41 & 4.23 & 1.082 \\
\hline & WC7 Persisting ${ }^{\mathrm{b}}$ & 23.92 & 3.463 & 24.39 & 3.596 & 24.40 & 3.85 & 0.456 \\
\hline & WC8 Adapting to Change ${ }^{\mathrm{c}}$ & 18.51 & 4.432 & 18.39 & 4.321 & 18.58 & 4.57 & 0.042 \\
\hline & WC9 Working in Teams ${ }^{\mathrm{a}}$ & 19.55 & 4.041 & 19.35 & 3.435 & 20.22 & 4.60 & 1.131 \\
\hline
\end{tabular}

Note. Pre $=$ pre-clinical; Post $=$ post-clinical

${ }^{\mathrm{a}} n=258 .{ }^{\mathrm{b}} n=259 .{ }^{\mathrm{c}} n=260 .{ }^{\mathrm{d}} n=261 .{ }^{\mathrm{e}} \mathrm{n}=262$.

$* p<.05$ 
significant different was seen for competency WC4, as a sense of quality, between students with different levels of academic achievement (see Table 11). There were also significant differences seen between students based on the number of credits being awarded for the completion of the clinical experience. It was further revealed that there was a significant difference in the preclinical score for systems thinking (WC3) and the post-clinical score for competency WC6, information processing (see Table 12). No significant differences were found between the mean scores based on the size of the student's institution (see Table 13). A statistical analysis based on the total number of hours required to complete the clinical experience could not be performed due to the homogenous nature of the sample. There was no significant difference found in the student's pre-clinical scores or post-clinical scores based on the number of nursing students enrolled in the student's nursing degree program (see Table 14). 


\section{Chapter Five}

\section{Conclusions and Recommendations}

Purpose of the study

This study assessed whether Maryland community college students who participated in a nursing work-based learning clinical experience during the fall 2004 semester developed basic workplace competencies necessary to work effectively in the workplace. Three research questions guided this study:

1. What types of gains do students who participate in nursing clinical experiences demonstrate over time?

2. Are there significant differences in workforce competencies between students enrolled in nursing clinical experiences at community colleges that reflect exemplary policies and procedures versus students at community colleges that do not reflect exemplary policies and procedures?

3. Are there significant differences in workforce competencies for students by various demographic factors and institutional variables? These factors include previous work experience, age, academic achievement, and the number of credits the student will be awarded for the completion of the clinical experience. Selected institutional variables include institutional size and the size of an institutions associate degree of nursing program; that is the number of students enrolled in the institutions associate degree of nursing program.

\section{Conclusions}

\section{Research Question One}

This question examined the types of gains students who participated in nursing clinical experiences were expected to acquire. The study measured changes in students responses to nine 
competencies: (a) life-long learning (WC1), (b) permanent problem solving (WC2), (c) systems thinking (WC3), (d) a sense of quality (WC4), (e) taking responsibility (WC5), (f) information processing (WC6), (g) persisting (WC7), (h) adapting to change (WC8), and (i) working in teams (WC9).

The researcher hypothesized that there would be an increase in the pre-post workplace competencies scores of students that participated in the first semester of the work-based learning (WBL) experience for the associate degree of nursing (ADN) program. This assumption was based on the traditionally strong role that community colleges play in utilizing work-based learning (Bragg, Hamm, \& Trinkle, 1995) as part of their vocational education programs. Students engaged in a work-based learning experience more easily develop links between what is taught in the classroom to the skills necessary to adapt to the changing workplace environment than do students engaged in strictly on-campus classroom instruction (Stasz \& Stern, 1999). Furthermore, Bragg, Hamm, and Trinkle in their 1995 study of the scope of work-based learning in community colleges found that ADN programs are the most likely place within community colleges to find work-based learning strategies being implemented within the curriculum. Following this line of reasoning, this researcher speculated that nursing degree students would attain workplace skills, specifically basic workplace competencies, during their work-based learning clinical experience.

Contrary to this hypothesis, instead of showing gains, all nine measures either decreased or the gains were statistically insignificant (see Table 6). Three of the decreases were significant: (a) taking responsibility (WC5), (b) persisting (WC7), and (c) working in teams (WC9). While life-long learning increased, the result was not statistically significant.

Logically there appears to be two plausible explanations for these results. The first explanation is that students were not taught these competencies during their work-based learning 
clinical experience. The first semester of clinical experience is designed to develop the technical skills required by nursing students to provide basic patient care. Much emphasis is placed on teaching, developing, and measuring the attainment of these skills, potentially resulting in a deemphasis of the development of basic workplace competencies. The second entails the inherent errors in relying on results based on self-perceptions. The results of this study should be used cautiously because of the limitations inherent with using self-reported data to measure learning.

Although the study did not specifically address the norming of the data to specific competencies, students might be readjusting their attainment of workplace competency scores on the post-clinical experience questionnaire to reflect their actual levels of attainment at the beginning of the clinical experience. Experience gained through the first semester of the clinical experience may have allowed the students to more accurately assess their actual level of attainment of basic workplace competencies resulting in lower scores on the post clinical assessment.

Re-baselining attainment to lower levels may also be indicative of the fact that these competencies are not adequately addressed in the nursing curriculum. This is consistent with industry findings that students graduate without having attained the basic workplace competencies required to provide high quality and safe healthcare (National Academy of Sciences, 2003). Nurses of the future need to possess skills beyond what is currently being taught in associate degree of nursing programs (Pew Health Professions Commissions, 1998). The results of this study raise concerns that students may be completing the associate degree of nursing programs without having the very skills that allow them to grow and change within their profession.

The low post-clinical competency scores are consistent with the literature that indicates a long history of business and industry reporting a gap between the levels of basic workplace skills 
expected by employers and the actual levels of basic workplace skills of employees (Ivey, 2002;

National Alliance of Business [NAB], 2002b). Specific to healthcare, the literature also reports a shortage in the level of attainment of required workforce competencies by nurses in the workforce (USDHHS, 2001b). These skills help the nurse to adapt to the changing healthcare environment. These skills include: (a) problem solving, (b) interpersonal and communication skills, (c) critical thinking, (d) relationship management, (e) information literacy, (f) sensitivity to diversity, (g) creativity, (h) teamwork skills, and (i) ethical decision making (AACN, 2002; Carnevale \& Desrochers, 2001; NLNAC, 2003). This study demonstrates that the gap between the skills required in the workplace and the skills taught through associate degree of nursing programs may already exist as early as the first semester of the student's clinical experience. Research Question Two

The study did not find significant differences in the workforce competency scores between students enrolled in nursing clinical experiences at community colleges that reflect exemplary policies and procedures versus students at community colleges that do not reflect exemplary policies and procedures (see Table 7). The researcher expected that students that were enrolled in nursing degree work-based learning programs reflecting exemplary policies and procedures would exhibit greater gains than students from programs that did not reflect exemplary policies and procedures. A within samples test revealed that there were no significant differences in the pre-clinical and post-clinical competency scores of students from schools that reflected exemplary policies and procedures. However, students from schools that did not reflect exemplary policies and procedures did show significant decreases in the differences in their mean scores for competency WC7, persisting and competency WC9, working in teams (see Table 8) suggesting that students perceived that the curriculum in non-exemplary nursing degree programs did not improve their basic workplace competencies in these areas. Conversely, 
students in exemplary programs did not experience the same losses as students from nonexemplary programs suggesting that exemplary programs have incorporated the policies and procedures identified by Bragg and Hamm (1996).

Research Question Three

Research question three addresses gains in competencies in seven different areas: (a) previous work experience, (b) age, (c) academic achievement, (d) the number of credits the student will be awarded for the completion of the clinical experience, (e) institutional size, (f) total number of hours required to complete the clinical experience, and (g) the size of an institutions associate degree of nursing program. The study revealed that three of the demographic factors were significant. They were: (a) age, (b) academic achievement, and (c) size of the student's institution.

Previous Work Experience: Research showed that there were no significant differences in the students' competency scores based on each student's years of previous work experience (see Table 9). The hypothesis of this research was that students with more work experience should realize higher competency scores verses students with less work experience.

Age: Significant differences were seen in three competency scores of students grouped by age: (a) life-long learning (WC1), (b) a sense of quality (WC4) and (c) adapting to change (WC8) (see Table 10). Specifically, students age 18-22 scored lower in their pre and postclinical scores for competency WC1, life-long learning, than did students age 23-30, students age 31-38, and students 39 years of age or older. The hypothesis of this research was that older students should realize higher competency scores verses younger students. The data is consistent with this hypothesis suggesting that younger students had statistically lower competency scores for life-long learning (WC1) competency than did the other age groups. 
It was also demonstrated that students 18-22 years of age scored lower in their pre and post-clinical scores for competency WC4, a sense of quality, than did students 39 years of age or older. The data suggests that younger students (18-22 years of age) did not self identify themselves as having a sense of quality verses students that were more mature (39 years of age or older). Students age 18-22 scored lower in their pre and post-clinical scores for competency WC8, adapting to change, than did students 39 years of age or older. The data suggests that younger students (18-22 years of age) did not self identify themselves as having a sense of being able to adapt to change verses students that were more mature (39 years of age or older).

Academic Achievement: A significant difference was seen for post-clinical competency score WC4, as a sense of quality, between students with different levels of academic achievement (see Table 11). The data confirms the researcher’s hypothesis; students with a higher grade point average (GPA) have a higher sense of quality for their work than students with a lower GPA.

Credits Awarded: There were also significant differences seen between students based on the number of credits being awarded for the completion of the student's clinical experience. The researcher hypothesized that students that were awarded more credits for the clinical experience would have higher competency scores. The study revealed a significant difference in the preclinical score for systems thinking (WC3) and the post-clinical score for competency WC6, information processing (see Table 12). The data suggested that students who were awarded between 4-6 credits had a significantly higher pre-clinical score for competency WC3, systems thinking, than did students that took 7 or higher credits and a higher post-clinical score for competency WC6, information processing, than did students that were awarded between 1-3 credits or students that were awarded 7 or higher credits. 
Institutional Size: No significant differences were found between the mean scores based on the size of the student's institution (see Table 13). The researcher hypothesized that students enrolled in larger institutions would realize higher competency scores than students from smaller institutions.

Total Number of Hours Required for Completion: A statistical analysis based on the total number of hours required to complete the clinical experience could not be performed due to the homogenous nature of the sample. All students participating in this study were required to complete over 31 hours of clinical experience at the worksite.

Size of Student's Nursing Program: There was no significant difference found in the student's pre-clinical scores or post-clinical scores based on the number of nursing students enrolled in the student’s nursing degree program (see Table 14).

Summary Conclusion

1. Students perceived that they did not develop basic workplace competencies during the work-based learning clinical experience. All nine measures either decreased or the gains were statistically insignificant. Three of the decreases were significant.

2. Much emphasis is placed on developing the technical skills of the students during the first semester clinical experience resulting in a lack of emphasis or a de-emphasis on the development of basic workforce competencies.

3. Students may be re-norming their scores on the post-clinical experience questionnaire to reflect their actual levels of attainment of basic workplace competencies resulting in lower scores on the post-clinical assessment.

4. Students perceived that the curriculum in non-exemplary nursing degree programs did not improve their basic workplace competencies. 
5. Students in exemplary programs did not experience the same losses as students from non-exemplary programs suggesting that exemplary programs have incorporated the exemplary policies and procedures as identified by Bragg and Hamm (1996).

6. Younger students (18-22 years of age) did not self identify themselves as having as high of confidence in their skill levels as older students.

7. Students with a higher grade point average (GPA) have a higher sense of quality for their work than students with a lower GPA.

8. Although statistically significant, the results based on the number of credits the student was awarded for the completion of the clinical experience were inconclusive.

\section{Recommendations}

\section{Recommendations for Practice}

The researcher has five recommendations for practitioners.

1. Nursing Program coordinators need to develop an ongoing assessment system which measures the attainment of basic workplace competencies. Specifically, a formative type of assessment should be used to measure the attainment of basic workplace skills early in the nursing curriculum to determine if students are prepared to enter the work-based learning clinical experience.

2. Measure basic workplace competencies throughout the entire nursing curriculum. The development of basic workplace competencies requires a systematic integration of teaching and assessment methods across the entire nursing degree curriculum.

3. Basic workplace competencies skills need to be reinforced and measured as part of the work-based learning experience, as this is the optimal time within the nursing curriculum to teach students how these skills allow the student to acquire and integrate new knowledge within a complex, changing, and diverse working 
environment. Basic workplace competencies are required to learn other skills and are not being reinforced in the nursing curriculum (Pew Health Professions Commissions, 1998). Nursing education practitioners may argue that the first semester of the clinical experience is meant to develop the technical skills (i.e. basic patient care techniques) required to work in the workplace. But, these skills can not be taught at the expense of basic workplace skills.

4. Practitioners need to develop strategies that focus on the support and development of basic workplace competencies in associate degree of nursing students. Faculty need to build in elements of design into the curriculum that identify competency gaps and implement remedial training to address the gaps.

5. Employers need to develop an induction phase to the hiring process before new employees begin in the workplace. This induction phase should consist of an orientation and training that reinforces the development of basic workforce skills and competencies necessary to work effectively in the changing healthcare field.

\section{Recommendations for Further Research}

Ten recommendations are made:

1. Studies should be conducted to analyze whether or not the teaching of basic workplace competencies are being incorporated into the curriculum. Because the focus of the nursing program is primarily on teaching demanding technical skills, basic workplace competencies may have a lower priority as part of the overall systematic delivery of the nursing curriculum. Measuring student competencies throughout the nursing curriculum would help nursing programs to identify whether or not the results of this study are consistent with other semesters within the nursing curriculum. 
2. Additional research is recommended to triangulate the results of this study. This research was collected from the student's perspective. Measuring the attainment of student's competency skills from the perspective of the faculty and employer would greatly enhance the results and validity of future studies.

3. Expand the study to include measuring basic workplace competencies over more than one semester of the associate degree of nursing (ADN) program. Practitioners and researchers need to measure the attainment of basic workplace competencies throughout the entire ADN curriculum, not just during the work-based learning clinical experience. A longitudinal study of the attainment of basic workplace skills throughout the curriculum would either confirm or deny the results obtained through this study.

4. Measurement of student competencies by faculty and employers throughout the clinical experience would help to validate or nullify the student's own perceptions of their attainment of basic workplace competencies.

5. Utilize other research designs methods (e.g. mixed method, case study, qualitative) to uncover the depth of the issues affecting the attainment of basic workplace competencies by nursing students. A mixed methods study would allow researchers to uncover the depth of the issues.

6. Research should be conducted to determine the degree that exemplary policies and procedures, as identified by Bragg and Hamm (1996), have been implemented in exemplary work-based learning programs in associate degree of nursing programs (ADN). These factors are: (a) strong program leadership, (b) exclusive connections between the program and its environment, (c) frequent and effective communications with local employers, (d) beliefs about program excellence, (e) a program with 
effective school-based learning component, (f) adequate and diverse financial support, and (g) innovative program and pedagogical features. An in-depth study would help to determine the true extent of the implementation of these factors within the exemplary ADN programs.

7. An in-depth research study should be conducted to determine whether or not the exemplary policies and procedures, as identified by Bragg and Hamm (1996), have been implemented in exemplary work-based learning associate degree of nursing programs. An in-depth study would allow practitioners to identify which of the polices and procedures are being implemented and to what extent the individual policies and procedures play in the attainment of each basic workplace competency. Strong policies and procedures ensure that work-based learning programs have strong links with their environment.

8. An attempt should be made determine the optimal number of credits (i.e. student course workload) a student should be awarded for the completion of each semester of the clinical experience.

9. Additionally, it is recommended that a study be conducted to determine the optimum number of students enrolled in an associate degree of nursing program. With the shortage of nurses, attention needs to be paid to providing quality curriculum to as many students as possible without overextending the resources of the college's associate degree of nursing program (e.g. facilities, faculty, staff, and financial).

9. Further research is recommended to determine the optimal program size to include appropriate student to instructor ratios. Although not measured in this study, student to instructor ratios play a critical role in the ability of students to attain new knowledge. 
10. Research should be conducted beyond Maryland to determine if the issues uncovered by this research extend beyond the borders of the State. 


\section{References}

American Association of Community Colleges. (2002). The nursing shortage and the role of community colleges in nurse education (Issue Brief No. AACC-RB-02-5). Annapolis Junction, MD: Author.

American Association of College Nursing. (2002). Nursing educators agenda for the $21^{\text {st }}$ century. Washington, DC: Author.

The American Diploma Project. (2002). National new economy workplace study. Retrieved March 29, 2003, from http://www.americandiplomaproject.org/ workplace.html

American Society for Training and Development. (1989a). Training America: Learning to work for the $21^{\text {st }}$ century. Alexandria, VA: Author.

Atkinson, R. D., \& Coduri, R. (2002, June). The 2002 state new economy index: Benchmarking economic transformation in the states. Washington, DC: The Progressive Policy Institute.

Bailey, T., \& Averianova, I. E. (1998). Multiple missions of community colleges: Conflicting or complementary? New York: Columbia University, Community College Research Center Institute on Education and the Economy.

Bragg, D. D., Hamm R. E., \& Trinkle, K. A. (1995, February). Work-based learning in two-year colleges in the United States. Berkeley: University of California, National Center for Research in Vocational Education.

Bragg, D. D., \& Hamm R. E. (1996, April). Linking college and work: Exemplary policies and practices of two-year college work-based learning programs. Berkeley: University of California, National Center for Research in Vocational Education.

Carl D. Perkins Vocational and Applied Technology Education Amendments of 1998, H.R. 1853, 105d Cong. (1998). 
The Carnegie Foundation for the Advancement of Teaching. (2000). The Carnegie Classification of Institutions of Higher Education. Stanford, CA: Author. Retrieved September 28, 2003, from http://www.carnegiefoundation.org/classification/cihe2000/ defnotes/definitions.htm

Carnevale, A. P. (1991). America and the new economy. Alexandria, VA: ASTD.

Carnevale, A. P., \& Desrochers, D. M. (2001). Help wanted...credentials required: Community colleges in the knowledge economy. Annapolis Junction, MD: Community College Press.

Carnevale, A. P., Gainer, L. J., \& Meltzer, A. S. (1990). Workplace basics: The essential skills employers want. San Francisco: Jossey-Bass.

Carnevale, A. P., \& Johnston, J. W. (1989). Training America: Strategies for the nation. Alexandria, VA: ASTD.

Cohen, A. M., \& Brawer, F. B. (1996). The American community college (3rd ed.). San Francisco: Jossey-Bass.

Coley, R. J. (2000). The American community college turns 100: A look at its students, programs, and prospects. Princeton, NJ: Educational Testing Service.

Commission on the Skills of the American Workforce. (1990). America's choice: High skills or low wages! Washington DC: National Center on Education and the Economy.

Dougherty, K. J. (2001). The contradictory college: The conflicting origins, impacts, and futures of the community college. Albany, NY: State University of New York Press.

Dougherty, K. J., \& Bakia, M. F. (1999). The new economic development role of the community college. New York: Columbia University, Community College Research Center.

Eaton, J. S. (1993). Redirecting the American dream: The community college as a democratizing institution. Catalyst, 23, 3. Retrieved May 8, 2003, from http://scholar.lib.vt.edu/ ejournals/CATALYST/V23N3/eaton.html 
Eyler, J. (1994, Winter). Comparing the impact of two internship experiences on student learning. Journal of Cooperative Education, 29(3), 41-52.

Frankel, J. R., \& Wallen, N. E. (2000). How to design and evaluate research in education. Boston: McGraw-Hill.

Florida Department of Education. (1995, September). Florida's system of school improvement and accountability: Blueprint 2000. Tallahassee, FL: Author.

Goodin, H. J. (2003). The nursing shortage in the United States of America: An integrative review of the literature. Journal of Advanced Nursing, 43(3), 335-350.

Governor's Workforce Investment Board and RESI Research and Consulting. (2001). 2001 State of the Workforce Report. Annapolis, MD: Governor’s Workforce Investment Board.

Grubb, W. N. (1994, Winter). The sub-baccalaureate labor market and the advantages of cooperative education. Journal of Cooperative Education, 30(2), 6-19.

Grubb, W. N. (1996). Working in the middle. San Francisco: Jossey-Bass.

Grubb, W. N., Dickinson, T., Giordano, L., \& Kaplan, G. (1992). Betwixt and between: Education, skills, and employment in sub-baccalaureate labor markets. Berkeley, CA: University of California, National Center for Research in Vocational Education. Halperin, S. (1998). The forgotten half revisited. Washington, DC: American Youth Policy Forum.

Interagency Collaborative on Nursing Statistics. (2003). Nurses, Nursing Education, and Nursing Workforce: Definitions. Retrieved February 27, 2004, from http://www.iconsdata.org /educationrelated.htm

Information Technology Association of America. (ITAA), (2001, April). When can you start? building better information technology skills and careers. Arlington, VA. 
Information Technology Association of America. (ITAA), (2003, May). 2003 Workforce Survey. Arlington, VA.

Ivey, S.G. (2002). Workplace competencies (SCANS) of job applicants as reported by human resource personnel (Doctoral Dissertation, University of Missouri-Columbia, 2002). Dissertation Abstracts International, 63, 05A.

Johnston, W., \& Packer, A. (1987, June). Workforce 2000: Work and workers for the twenty-first century. Indianapolis, IN: Hudson Institute.

Kane, M., Berryman, S., Goslin, D., \& Meltzer, A. (1990). Identifying and describing the skills required by work. Washington, DC: Pelavin Associates.

Laanan, F. S. (1995). Community colleges as facilitators of school-to-work. Los Angeles, CA: ERIC Clearinghouse for Community Colleges. Retrieved March 2, 2003, from http://www.eric-facility.net/ericdigests/ed383360.html

Maduschke, K. M., \& Grummon, P. T. (1996, June). Technical documentation to working. Lansing, MI: Public Policy Associates.

Maryland Association of Community Colleges. (2001). Addressing Maryland’s critical workforce shortages: A strategic vision form Maryland’s community colleges. Annapolis, MD.

Maryland Board of Nursing. (2002). Workplace survey2001. Baltimore: Maryland Department of Health and Mental Hygiene.

Maryland Board of Nursing. (2003). A guide to nursing education in Maryland. Retrieved February 25, 2004, from http://www.mbon.org/ main.php?v=norm\&p=0\&c=education/ nsg_guide/progam_types.html

Maryland Higher Education Commission. (2002). Data book: Maryland Higher Education Commission. Annapolis, MD: Author. 
Maryland Higher Education Commission. (2003). Trends in enrollment by program: Maryland higher education institutions. Annapolis, MD: Author.

Maryland Higher Education Commission. (2005). Data book: Maryland Higher Education Commission. Annapolis, MD: Author.

Maryland State Department of Education. (1996, January). Skills for success core learning goals. [Revised draft presented to the Maryland State Board of Education]. Baltimore: Author. Mehrens, W. (1989). Michigan employability skills employer survey. Technical Report. East Lansing, MI: Michigan State University.

Miles, C. (1994). The Mindful Worker: Learning and Working into the $21^{\text {st }}$ Century. Lansing, MI: H\&H Publishing.

Miles, C., \& Grummon, P. (1996). Working: Assessing skills, habits, and style. Lansing, MI: H\&H Publishing.

National Academy of Sciences. (2003). Health professions education: A bridge to quality. Washington: DC.

National Alliance of Business. (2001, Fall). Skilled workforce shortage could cripple U.S. economy. Work America,18, 6.

National Alliance of Business. (2002a, Summer). Higher education: A rapidly changing landscape. Work America,19, 3.

National Alliance of Business. (2002b, September). The American diploma project workplace study. Washington, DC: Author.

National Center for Educational Statistics. (2002). Digest of Education Statistics, 2001 (NCES Publication No. 2002130). Washington, DC: Government Printing Office 
National Center for Educational Statistics. (2003a). Postsecondary institutions in the United States: Fall 2002 and degrees and other awards conferred: 2001-2002 (NCES Publication No. NCES 2004-154). Washington, DC: Government Printing Office.

National Center for Educational Statistics. (2003b). Digest of Education Statistics, 2002 (NCES Publication No. NCES 2003-060). Washington, DC: Government Printing Office.

National Center for Higher Education Management Systems. (2001, October). Community colleges and the future of Pennsylvania: An agenda for public policy. Boulder, CO: Author.

National Council for Occupational Education and American Association for Community and Junior Colleges. (1990). Productive America. Chicago: National Council for Occupational Education.

National Council of State Boards of Nursing. (2004a). 2003 nurse licensure examination statistics. Chicago: Author.

National Council of State Boards of Nursing. (2004b). Test plan for the national council licensure examination for registered nurses. Chicago: Author.

National League of Nursing Accrediting Commission. (2003). NLNAC 2003 edition: Interpretive Guidelines. New York: Author.

National Society for Experiential Education. (1998). Some experiential learning terms. Springfield: VA: Author. Retrieved April 10, 2003, from http://www.nsee.org/defn.htm Naylor, M. (1997). Work-based learning. Columbus, OH: ERIC Clearinghouse on Adult, Career, and Vocational Education. Retrieved October 3, 2002, from http://ericacve.org/docs/dig187.htm

New York State Education Department. (1990, July). Basic and expanded basic skills: Scales for validation study. Albany, NY: Author. 
O’Banion, T. (1999). Launching a learner-centered college. Mission Viejo, CA: League for Innovation in the Community College.

Oblinger, D., \& Verville, A.L. (1998). What business wants from higher education. Phoenix, AZ: The Oryx Press.

Overtoom, C. (2000). Employability skills: An update. Berkeley: University of California, National Center for Research in Vocational Education. (ED445236)

Packer, A. (1998, October). The end of routine work and the need for a career transcript. Paper presented at the Hudson Institute's Workforce 2020 Conference, Indianapolis, IN.

Perry, N.S. (1992). Educational reform and the school counselor. Ann Arbor, MI: University of Michigan, ERIC Clearinghouse on Counseling and Personnel Services. (ED347491)

Pew Health Professions Commissions. (1998). Recreating health professional practice for the new century. San Fransico.

Ratcliff, C. W., \& Zirkin, B. G. (1986). Vocational-technical education program articulation and linkages in Maryland. Catonsville, MD: Maryland University, Maryland Institute for Policy Analysis and Research.

Russell, J., \& Coffey, M. (1993). Skills for industrial modernization. Dearborn, MI: Modernization Forum Skills Commission.

Ryder, K. G. (1987). Cooperative education in a new era. San Francisco: Jossey-Bass.

School-to-work Opportunities Act of 1994 (STWOA), P.L. 103-239, 103d Cong. (1994).

Stasz, C., \& Stern, D. (1999, Winter). Work-based learning for students in high schools and community colleges. NSEE Quarlerly, 25(2), 8-14.

Stasz, C., Ramsey, K., Eden, R., Melamid, E., \& Kaganoff, T. (1996). Workplace skills in practice: Case studies of technical work. Berkeley, CA: University of California, National Center for Research in Vocational Education. 
Suskie, L. A. (1996). Questionnaire survey research: What works. Tallahassee, FL: Association for Institutional Research.

Szocki, D. F., \& Bolt, L. (2000, Fall). Workforce improvement network 2000 survey of Virginia employees in fall of 2000. Harrisonburg, VA: Workforce Improvement Network.

Toohey, S., \& Ryan, G. (1996, September) Assessing the practicum. Assessment and Evaluation in Higher Education, 21(3), 215-228.

Urquiola, M., Stern, D., Horn, I., Dornsife, C., Chi, B., Williams, L., Merritt, D., Hughes, K., \& Bailey, T. (1997). School to work, college and career: A review of policy, practice, and results 1993-1997 (MDS-1144). Berkeley, CA: National Center for Research in Vocational Education, University of California at Berkeley.

U.S. Census Bureau. (2002, September 23). Annual demographic survey: March supplement. Retrieved June 7, 2003, from http://ferret.bls.census.gov/macro/032002/ perinc/new03_001.htm

U.S. Department of Education. (1994). National assessment of vocational education: Final report to congress. Washington, DC: Office of the Under Secretary, Planning and Evaluation Service.

U.S. Department of Education. (2002). National assessment of vocational education: Interim report to congress. Washington, DC: Office of the Under Secretary, Planning and Evaluation Service.

U.S. Department of Health and Human Services. (2000). The registered nurse population: Findings from the national sample survey of registered nurses. Washington, DC: Bureau of Health Professions, Division of Nursing. 
U.S. Department of Health and Human Services. (2001a). The registered nurse population national sample survey of registered nurses - March 2000: Preliminary findings. Washington, DC: Bureau of Health Professions, Division of Nursing.

U.S. Department of Health and Human Services. (2001b). National Advisory Council on Nurse Education and Practice: Preliminary findings First report to the Secretary of Health and Human Services and the Congress.. Washington, DC: Bureau of Health Professions, Division of Nursing.

U.S. Department of Health and Human Services. (2002). Projected supply, demand, and shortages of registered nurses: 2000-2020. Washington, DC: Bureau of Health Professions, Division of Nursing.

U.S. Department of Labor. (1991a). The Secretary's Commission on Achieving Necessary Skills: Blueprint for action: Building community coalitions. Washington, DC: U.S. Government Printing Office.

U.S. Department of Labor. (1991b). The Secretary's Commission on Achieving Necessary Skills: What work requires of schools. Washington, DC: U.S. Government Printing Office.

U.S. Department of Labor. (1992a). The Secretary's Commission on Achieving Necessary Skills (SCANS): Learning and Living: A Blueprint for High Performance. Washington, DC: U.S. Government Printing Office.

U.S. Department of Labor. (1992b). Skills and tasks for jobs: A SCANS report for America 2000. Washington, DC: U.S. Government Printing Office.

Van Gyn, G., Cutt, J., Loken, M., \& Ricks, F. (1997, Winter). Investigating the educational benefits of cooperative education: A longitudinal study. Journal of Cooperative Education, 32(2), 70-85. 
Wilson, J. W., Stull, W. A., \& Vinsonhaler, J. (1996, Winter). Rethinking cooperative education. Journal of Cooperative Education, 31(2), 161-162.

Witt, A. A. (1988). The junior college movement: An historic review. Gainesville, FL: Institute of Higher Education, University of Florida. 


\section{Appendix A}

Nursing Program Coordinator Interview Questionnaire

1. College name

2. Agrees to participate? Yes No

3. Clinical experience beginning date

4. Clinical experience ending date

5. Number of students enrolled in the clinical experience in fall 2004

6. What is the number of students currently enrolled in the ADN program at your institution 


\section{Appendix B}

\section{Pre-clinical Experience Cover Letter to the Nursing Program Coordinator}

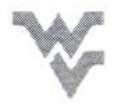

\section{WestVirginiaUniversity}

College of Human Resources and Education

\author{
WEST VIRGINIA UNIVERSITY \\ Institution Review Board for the \\ Protection of Human Research Subjects \\ JUL 012004 \\ APPROVED
}

Date:

Address:

Dear Nursing Program Coordinator

Thank you for agreeing to participate in my research study of workforce competencies and workbased learning in Maryland community college nursing program. This research is being conducted by Richard Ammon, a doctoral candidate, to fulfill the requirements for a degree in Educational Leadership Studies in the Department of Human Resources and Education at West Virginia University, under the supervision of Dr. Richard Hartnett, Ed.D. One of the traditional missions of community colleges is to prepare members of the community to work in their communities. The purpose of my study is to determine if community college students who participated in work-based learning clinical experiences developed basic workplace competencies necessary to work effectively in a the workplace. This research will examine the connection between the skills required in the workplace and what is being taught in higher education.

The survey process has three major parts.

1. Nursing Program Coordinator, please complete the attached brief questionnaire requesting information about the nursing program at your college. The questionnaire will take no longer than five minutes of your time to complete. Your responses on the questionnaire will be held confidential and your institution will not be mentioned by name in my dissertation. Your participation is voluntary. The questionnaire needs to be returned to me no later than 9/15/04.

2. The next phase of the research will consist of the students completing a short demographic questionnaire and a pre-test instrument titled Working: Assessing Skills, Habits, and Style. I will schedule a time to visit your college to administer this phase of the research. When I arrive I will read the student cover letter and questionnaire directions aloud to students inviting them to participate. I will then ask students who are pursuing a nursing degree and are enrolled in their first clinical experience in fall 2004 to complete the student demographic questionnaire and the Working: Assessing Skills, Habits, and Style questionnaire. Each student recèves a cover letter, student demographic questionnaire, and Working: Assessing Skills, Habits, and Style questionnaire (I have provided a copy for your review). I will need to administer the documents by the end of the first week of the fall 2004 semester. Ideally I am trying to get $50 \%$ or more of the students to participate. Once the students have completed the student demographic questionnaire and the Working: Assessing Skills, Habits, and Style questionnaire I will pick them up. 
In the final phase of the research I will administer a brief demographic questionnaire and the post-clinical experience instrument. This phase needs to be completed at the end of the fall 2004 semester or at the end of the clinical experience. Again, I will read the student cover letter aloud to students inviting them to participate.

The responses on the questionnaires will be held confidential and your institution will not be mentioned by name in the dissertation. Your participation and the student's participation are voluntary. If you choose, you do not have to answer every question. At the time of completion, I could send you an executive summary of my dissertation.

For more information about this research, you can contact Richard Ammon, at (301) 846-2684, or his supervisor, Dr Richard Hartnett, Ed.D at 304-293-3707 ext. 1422. For information regarding your rights as a research subject, you may contact the Office of Research Compliance at 304/2937073.

Thank you for your help,

Richard Ammon

Doctoral Candidate

West Virginia University

Rammon@frederick.edu 


\section{Appendix C}

Work-based Learning Program Dimensions Questionnaire to the Nursing Program Coordinator

Work-based Learning Program Dimensions Questionnaire to the Nursing Program Coordinator

\section{Instructions}

Please complete this short questionnaire and return it using the enclosed postage stamped envelope by $9 / 15 / 04$. Thank you for your consideration.

1. Please list the name(s) of the person(s) in charge of the nursing degree student clinical experience at your institution:

Department

Address

Town, State, Zip

Telephone Number

Email
Department

Address

Town, State, Zip

Telephone Number

Email

2. Please rate your agreement/disagreement with the following statement.

\begin{tabular}{|c|c|}
\hline $\begin{array}{l}\text { Strongly } \\
\text { Aoree }\end{array}$ & Agree \\
\hline
\end{tabular}

\section{The nursing program at this college:}

1. Has strong leadership by either an individual or a team/group

2. Is considered the competitive leader in the community for providing nursing clinical experiences

3. Has developed strong relationships between the nursing program and important community nursing organizations

4. Is considered by business/industry to have an economic impact on the community because they provide students with increased work-based skills

5. Has frequent communications with local employers with health organizations

Go to Next Page $\Rightarrow$ 
The nursing program at this college:

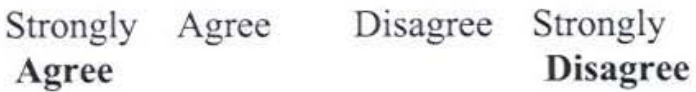

6. Has effective communications with local employers about the skills needed for employment (i.e. the college has a history of responding to the needs of the community)

7. Has a reputation of excellence within the college

8. Has a reputation of excellence within the community

9. Has strong relationships with other departments in the college that provide support and services to the program

10. Has adequate financial support (enough to strategically plan for the growth and development of the program)

11. Has multiple financial sources of support (e.g., local government, state government, federal government, local industry)

12. Has innovative program features such as:

a) Structured individualized student clinical experience plans

b) Mentoring system for clinical experience student

c) Articulation agreements with other secondary, two-year or four-year institutions of education

d) Flexible and adaptability formats (i.e. nursing curriculum is able to adapt to the needs of the community)

e) Student maintained portfolio of their work

f) Performance-based outcomes assessment of student progress 


\section{Appendix D}

\section{Student Information and Consent Form}

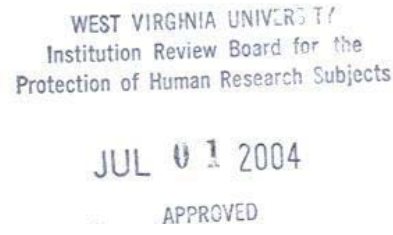

College of Human Resources and Education

\section{CONSENT AND INFORMATION FORM}

Workforce Competencies and Work-based Learning in

Maryland Community College Nursing Programs

\section{Introduction}

I, , have been invited to participate in this research study which has been explained to me by Richard Ammon. This research is being conducted by Richard Ammon, a doctoral candidate, to fulfill the requirements for a doctoral dissertation in Educational Leadership Studies in the Department of Human Resources and Education at West Virginia University, under the supervision of Dr. Richard Hartnett, Ed.D.

\section{Purposes of the Study}

The purpose of this study is to determine if community college nursing students who participated in a work-based learning clinical experience developed basic workplace competencies necessary to work effectively in the workplace. This study examines whether community college students who participated in nursing work-based learning clinical experiences developed basic workplace competencies necessary to work effectively in the workplace. The population studied will be Maryland community college students pursuing an associate degree in nursing who are enrolled in their first work-based learning clinical experience.

\section{Description of Procedures}

I have been told to fill out 4 questionnaires, 2 asking me for demographic information, which takes approximately 5 minutes each to complete and two questionnaires asking about workplace skills, which takes approximately 20 minute each to complete. I have been told that I may see the questionnaire before signing this consent and that I do not have to answer all the questions if I decide to participate. Approximately 2,000 subjects are expected to participate in this study.

Submission date

Page 1 of 3

$\overline{\text { initials }} \quad \overline{\text { date }}$


Workforce Competencies and Work-based Learning in Maryland Community College Nursing Programs

Risks and Discomforts

There are no known or expected risks from participating in this study.

\section{Alternatives}

I understand that I do not have to participate in this study.

\section{Benefits}

I understand that this study is not expected to be of direct benefit to me, but the knowledge gained may be of benefit to others.

\section{Contact Persons}

For more information about this research, I can contact Richard Ammon, at (301) 8462684, or his supervisor, Dr Richard Hartnett, Ed.D. at 304-293-3707 ext. 1422. For information regarding my rights as a research subject, I may contact the Office of Research Compliance at 304/293-7073.

\section{Confidentiality}

I understand that any information about me obtained as a result of my participation in this research will be kept as confidential as legally possible. I understand that my research records and test results, just like hospital records, may be subpoenaed by court order or may be inspected by the study sponsor or federal regulatory authorities (including the FDA if applicable) without my additional consent. In any publications that result from this research, neither my name nor any information from which I might be identified will be published without my consent.

Submission date

Page 2 of 3

$$
\text { initials }
$$$$
\text { date }
$$ 
Workforce Competencies and Work-based Learning in Maryland Community College Nursing Programs

\section{Voluntary Participation}

Participation in this study is voluntary. I understand that I am free to withdraw my consent to participate in this study at any time and that such refusal to participate will not affect my class standing or grades. Refusal to participate or withdrawal will involve no penalty to me. I have been given the opportunity to ask questions about the research, and I have received answers concerning areas I did not understand. In the event new information becomes available that may affect my willingness to continue to participate in the study, this information will be given to me so I may make an informed decision about my participation.

Upon signing this form, I will receive a copy.

I willingly consent to participate in this research.

$\overline{\text { Signature of Subject or Subject's Legal Representative }}$

$\overline{\text { Date }} \quad \overline{\text { Time }}$

Signature of Investigator or Co-Investigator

$\overline{\text { Date }} \quad \overline{\text { Time }}$

Submission date

Page 3 of 3 


\section{Appendix E}

\section{Pre-clinical Experience Student Demographic Characteristic Questionnaire}

\section{Student Demographic Characteristic Survey}

\section{Instructions}

This is part one of a two-phase study. Please complete this short survey and return it along with the Working: Assessing Skills, Habits, and Style pre-clinical experience questionnaire to your survey proctor. You will be given the Working: Assessing Skills, Habits, and Style post-clinical experience questionnaire (phase two) after the completion of your clinical experience. It is important that you complete each question accurately and completely. Please darken the oval of the response that indicates the best response. Thank you for your consideration.

1. Please indicate the last four digits of your social security number.

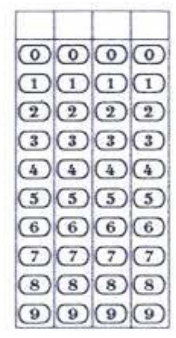

3. Please indicate your age.
18 to 22
23 to 30
31 to 38
39 to 46
47 to 54

55 or older
2. Please indicate the college you are currently attending.

Allegany College of Maryland

Anne Arundel Community College

Baltimore City Community College

The Community College of Baltimore County

Cecil Community College

Chesapeake College

College of Southern Maryland

Frederick Community College

Hagerstown Community College

$\checkmark$ Harford Community College

Howard Community College

$\checkmark$ Montgomery College

Prince Georges Community College

Wor-Wic Community College

Other

4. Please indicate your years of full-time previous work experience. (Please mark only one category.) 1 to 10

11 to 20

21 to 30

$\checkmark$ Over 31

5. Please indicate your cumulative academic grade point average.

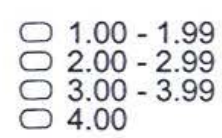

6. How many credits are you being awarded for the completion of your clinical experience? (Please mark only one category.)

1 to 3

4 to 6

7 or higher

7. Please indicate the total number of hours required at the work site to complete your clinical experience. 1 to 10

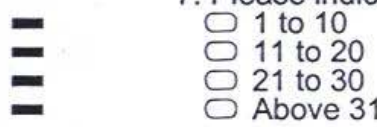




\section{Appendix F}

\section{Post-clinical Experience Cover Letter to Students}

West VirginiaUniversity
College of Human Resources and Education

Date

Dear student:

Thank you for participating in phase one of my study. I need your help to complete the final step of the study in workforce competencies and work-based learning in Maryland community college nursing programs. This research is being conducted by Richard Ammon, a doctoral candidate, to fulfill the requirements for a degree in Educational Leadership Studies in the Department of Human Resources and Education at West Virginia University, under the supervision of Dr. Richard Hartnett, Ed.D. You have been selected to participate in this study because you are enrolled in a nursing program at your college.

Attached you will find a two questionnaires. The first is a brief questionnaire designed to collect demographic information from you. This part of the questionnaire will take no longer than few minutes of your time to complete. The second section of the questionnaire, entitled Working: Assessing Skills, Habits, and Style, is a short multiple-choice questionnaire. This part of the questionnaire should take no longer than 10-20 minutes. When you are finished with the questionnaires, return them to me.

Your responses on both questionnaires will be confidential and your participation is voluntary. If you choose, you do not have to answer every question. Your choice not to participate in this study will not jeopardize your course or college standing.

For more information about this research, you can contact Richard Ammon, at (301) 846-2684, or his supervisor, Dr Richard Hartnett, Ed.D at 304-293-3707 ext. 1422. For information regarding your rights as a research subject, you may contact the Office of Research Compliance at 304/2937073.

Thank you for your help

Richard Ammon

Doctoral Candidate

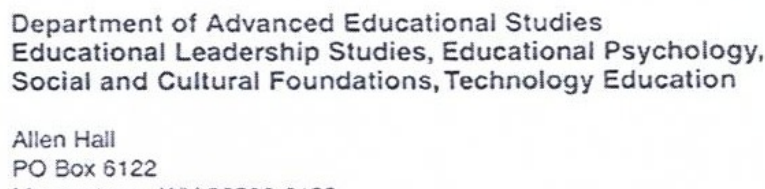




\section{Appendix G}

Post-clinical Experience Abbreviated Student Questionnaire

\section{Post-Clinical Experience Abbreviated Student Questionnaire}

\section{$\underline{\text { Instructions }}$}

This is part two of a two-part study. Please complete this short questionnaire and return it along with the Working: Assessing Skills, Habits, and Style post-clinical experience questionnaire. It is important that you complete each question accurately and completely. Thank you for your consideration.

1. Please darken the corresponding ovals of the last four digits of your social security number.

(5) (5) (5) (5)

(6) (6) (6) 6

(7) (7) (7) (7)

(8) (8) (8) 8

(9) (9) (9)

2. Please indicate the college you are currently attending.

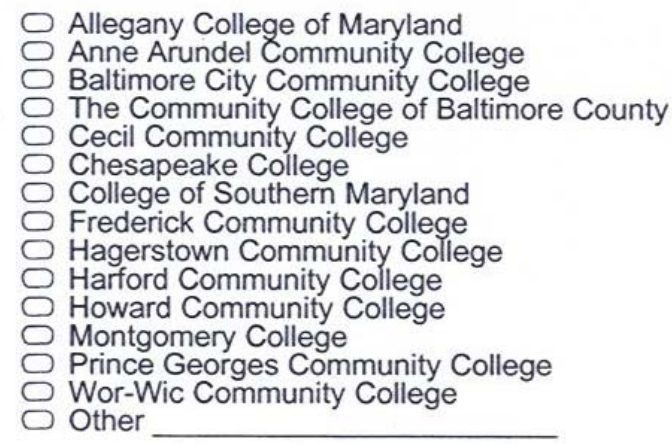




\title{
Appendix $\mathrm{H}$
}

\section{Working: Assessing Skills, Habits, and Style Questionnaire}

\section{WORKING}

We all bring our own habits, skills, and styles to work, school, community activities, and home life. Those personal characteristics often have a dramatic influence on what we do, how we do it, and how successful we are at our work.

Many of these characteristics are changeable, at least partly. If we find a characteristic that we like, we can strengthen it. If we find a characteristic that's getting in our way, we can in many cases modify it through time, attention, and effort. We can, in effect, get better at the tasks important to us.

WORKING helps you assess yourself on nine characteristics. For best results, respond to each item candidly. After scoring, you will have important information for planning improvements in your life.

\author{
Instructions for completing WORKING
}

On the page that follows, you will find 50 statements on front and back. You should respond to each statement by judging how well it describes you. How well does that statement fit you? Darken the oval of only one of the alternatives. An example (numbered 99) is shown below. Remember that this is not a 'test' -there are no right answers. Merely, your answers, based on your personality.

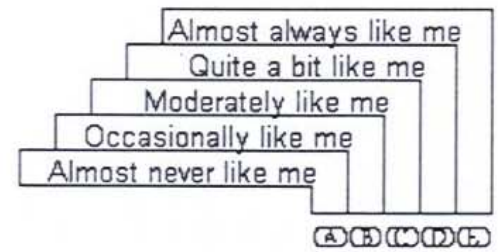

99. I like to learn more about myself by taking inventories like this.

When rating the survey questions please use the following criteria to evaluate:

A. Almost never like me - does not necessarily mean that the statement would never describe you, but it would only be true of you in rare instances. If this fits you, darken the oval A.

B. Occasionally like me - means that the statement would not usually be true of you, but would fit you every once in a while. If this fits you, darken B.

C. Moderately like me - means that the statement would be true of you fairly often. If this fits you, darken C.

D. Quite a bit like me - means that the statement would generally be true of you most of the time. If this fits you, darken D.

E. Almost always like me - does not necessarily mean that the statement would always describe you, but that it would be true of you almost all the time. If this fits you, darken E. 


\section{Working: Assessing Skills, Habits, and Style Questionnaire}

Permission to copy and use this survey was obtained from the author, Curtis Miles, Ph.D.(Miles@ped.tec.sc.us).

\begin{tabular}{|c|}
\cline { 2 - 2 } \multicolumn{1}{c|}{ Almost always like me } \\
\hline Quite a bit like me \\
\hline Moderately like me \\
\hline Occasionally like me \\
\hline Almost never like me \\
\hline
\end{tabular}

(A) $(B)(C)(D)(E)$ 1. I usually do something I enjoy rather than try something different.

$(A)(B)(C)$ (D) (E) 2. I do extra work to make sure things are done just right.

$(A)(B)(D)$ 3. I keep and use a list of things I've got to do.

(A) (B) (C) (D) (E) 4. I don't usually like others giving me suggestions on how I should do something.

$(A)(B)(D)$ (E) When learning something, I first think carefully about the very best way to tackle it.

$A(B)(D) 6$. I don't usually ask questions that go much beyond the immediate task at hand.

$(A)(B)(C)(D)$ (E) 7. I follow through on things no matter what it takes.

$(A)(B)(D)$. When solving a problem, I keep double-checking to be sure I'm right on track.

$(A)(B)(D)$. I I have found that group decisions are often better than individual decisions.

$(A)(B)(D)(E) 10.1$ worry a lot about what could happen when things are changing.

(A) (B) (C) (D) 11.1 tackle a problem by first trying to see how it affects others.

$(A)(B)(D)$ 12. I understand new things by seeing how they fit with what I already know.

$(A)(B)(D)$ 13. I check to make sure that others have done what they said they would do.

$(A)(B)(D)$ (14. I seek out new activities and responsibilities.

$(A)(B)(D)$ (D) 15. I get a job done, even when it's much harder that I first thought.

$(A)(B)(D)$ 16. I usually don't make a special effort to learn new things.

(A) (B) (C) (D) 17 . I make a detailed plan before I tackle a complex problem.

(A) (B) (C) (D) 18. I make a mental picture of what I'm trying to learn or solve.

$(A)(B)$ (E) 19. I frequently come up with new ideas for how to do things better.

$(A B)(C)(B) 20$. I'm usually most comfortable when things are predictable.

(A) (B) (C) (D) 21. I don't usually think about what I need to do until it's almost time to do it.

(A) (B) (C) (D) (E) 22. I explain to others why we need to work together.

(A) (B) (D) (D) 23. I like to experiment with ideas and possibilities in my head.

(A) (B) (C) (D) 24 . I don't let go of something until I understand it.

(A) (B) (C) (D) 25 . When trying to understand something complicated, I carefully break it into parts.

\section{Continue on next page}


Almost always like me Quite a bit like me Moderately like me Occasionally like me Almost never like me

(A) (B) (C) (D) (E) 26 . I want to see how one task is related to other tasks.

$(A)(B)(C)(E) 27$. I won't settle for just doing the minimum on anything, no matter what it is.

(A) (B) (C) (D) 28. I will offer a suggestion whenever I bring up a problem to someone.

(A) (B) (C) (D) (E) 29. I am uncomfortable when I have to handle several things at once.

(A) B (B) (D) 30 . It really bugs me to see a problem that nobody is trying to solve.

(A) (B) (D) 31 . I set definite goals, then keep working at them until I've achieved them.

(A) (B) (C) (D) (E) 32. I like working in teams.

(A) BCC(D) 33. When I have to wait, I will read anything I find lying around.

(A) (B) (C) (D) 34. I consciously ask myself questions to see how well I understand something.

(A) (B) (C) (D) 35. I can't quit thinking about something until I'm sure I've done it very well.

(A) (B) CC (D) 36 . It can take me a long time to get used to a major change in my life.

(A) (B) (C) (D) 37. As soon as I finish one task, I look for another one to do.

(A) (B) (C) (D) 38. If I can't catch on to something quickly, I sometimes just drop it.

(A) (B) (C) (D) (E) 39. I prefer to learn with other people.

$(A)(B)(D)$ (E) 40. I prefer to know what's in it for me before I spend a lot of effort learning something.

(A) (B) (C) (D) (E) 41. I consciously consider several different approaches before tackling a problem.

$(A) C(D)$ 42. I know how to get things done in a system or an organization.

(A) (B) (C) (D) 43 . I usually do my work with great care only if someone will be checking up on me.

$(A)(B)(B) 44.1$ prefer to let others take the lead in getting something done.

$(A)(B)(D) 45$. I learn by figuring out how I can apply the things I'm learning to my life.

(A) B(C) (D) 46 . I won't let go of a problem until l've got it licked.

$(A)(B)(D)(E) 47.1$ adapt quickly to new situations.

(A) (B) (D) (E) 48. I'm one of the first to volunteer to learn a new procedure or method.

(A) (B) (C) (D) 49 . I'Il frequently hold on to my opinion rather than compromise with the group.

(A) (B) (C) (D) 50.1 don't worry about the little details as long as I've done the main things okay. 


\section{Appendix I}

\section{Permission Letter from Author to Reproduce and Use Working Instrument}

\section{WestVirginiaUniversity \\ College of Human Resources and Education}

December 10, 2003

Dear Dr. Miles,

I am a doctoral candidate in Higher Educational Leadership Studies at West Virginia University. I need your help to complete my study in workforce competencies and workbased learning in Mid-Atlantic States community colleges. I am asking for permission to use and reproduce the assessment instrument Working: Assessing skills, habits, and style (1996) for my research. This letter will outline my research study and include instructions on how I intend to use the assessment instrument.

The purpose of my study is to determine if community college students that participate in work-based learning develop transferable workplace competencies necessary to work effectively in a high performance workplace. In order to do this, I am surveying students who are participating in work-based learning in higher education. Students will be administered the Working: Assessing skills, habits, and style assessment instrument before after their work-based learning experience.

The responses on the questionnaire and assessment instruments will be held confidential and institutions will not be mentioned by name in the dissertation. At the time of completion, I could send you an executive summary of my dissertation.

If you have any question, please do not hesitate to call. I can be reached at (301) 8462684 weekdays.

Thank you for your help,

Richard Ammon

Doctoral Candidate

West Virginia University

Rammon@frederick.edu

I hereby grant permission to Richard Ammon to reproduce and use the Working: Assessing skills, habits, and style (1996) assessment instrument as stated above.

Dr. Curtis Miles Date

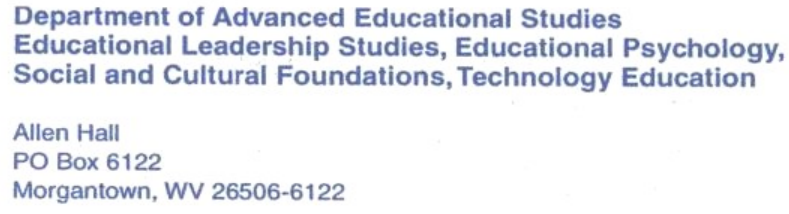

